\title{
Passive strategies used in Southern Portugal vernacular rammed earth buildings and their influence in thermal performance
}

\author{
Jorge Fernandes ${ }^{\text {a, }}{ }^{*}$, Ricardo Mateus ${ }^{\text {a }}$, Helena Gervásio ${ }^{\text {b }}$, Sandra M. Silva ${ }^{a}$, Luís Bragança a \\ a CTAC, Department of Civil Engineering, University of Minho, Campus de Azurém, 4800-048 Guimarães, Portugal \\ b ISISE, Department of Civil Engineering, University of Coimbra, Faculdade de Ciências e Tecnologia, Rua Luís Reis Santos, Pólo II, 3030-788 Coimbra, \\ Portugal
}

\section{A R T I C L E I N F O}

\section{Article history:}

Received 5 December 2018

Received in revised form 15 April 2019

Accepted 19 April 2019

Available online 28 April 2019

\section{Keywords:}

Vernacular earthen architecture

Rammed earth

Thermal performance

Indoor comfort evaluation

Passive cooling strategies

Bioclimatic

\begin{abstract}
A B S T R A C T
In Portugal, there is a lack of quantitative studies on the thermal performance of earthen buildings. This paper aims at contributing to this research context by studying site-specific strategies, and the thermal performance and comfort conditions of a rammed earth building located in southern Portugal. The study is based on objective and subjective assessments and consists of assessing the hygrothermal conditions, thermal comfort levels and analysing the occupants' perception regarding thermal sensation. The results showed that the strategies used are closely related to local conditions, mitigating the effects of high summer temperatures and ensuring a good summer thermal performance by passive means alone. During the summer monitoring, results showed that the building stayed most of the time (80\%) in Category I (high level of expectation) and the remaining time in Category II, according to the classification method defined by the standard EN15251. During the winter period, the building had the worst performance, being necessary a heating system to guarantee comfort conditions. Additionally, the results showed that the good thermal performance of the case study depended more on the high thermal inertia than on the U-value of the envelope. Limitations and advantages of the use of earthen construction elements are discussed.
\end{abstract}

(c) 2019 Elsevier Ltd. All rights reserved.

\section{Introduction}

\subsection{Context}

During recent years, the building sector has undergone a paradigm shift. The rise of environmental awareness has highlighted several problems regarding energy efficiency and environmental impacts. Thus, the sector is changing from a paradigm relying mainly on mechanical systems and high embodied energy materials, less concerned about the climate context and environmental impacts of buildings, to a holistic (sustainable) approach. Buildings are a key sector to implement energy and environmental measures since it is one of the largest energy and natural resources consuming sectors [1], responsible for a third of global total primary energy use and $\mathrm{CO}_{2}$ emissions [2,3]. In the European Union

\footnotetext{
* Corresponding author.

E-mail addresses: jepfernandes@me.com (J. Fernandes), ricardomateus@civil uminho.pt (R. Mateus), hger@dec.uc.pt (H. Gervásio), sms@civil.uminho.pt (S.M. Silva), braganca@civil.uminho.pt (L. Bragança).
}

(EU), for example, the Directive 2018/844 has set the long-term 2050 goal of reducing greenhouse gas emissions by $80-95 \%$, compared to 1990 , ensuring an energy efficient and decarbonised building stock and facilitating the cost-effective transformation of existing buildings into nearly zero-energy buildings (nZEB) [4].

The transposition of the EPBD-recast into national legislation [5] has defined requirements which can limit and constrain the use of vernacular building elements as they had so far been used. In this context, the Architecture, Engineering and Construction (AEC) professionals in the field of earthen construction argue that the thermal requirements in force are too strict, namely the heat transfer coefficient (U-value), and do not take into consideration other properties of earthen construction such as the very high thermal inertia. The professionals also argue that the study of the real thermal performance of such buildings is necessary to understand whether this type of constructions can meet current energy and comfort requirements.

Therefore, it is important to analyse possible limitations posed by the thermal regulation in the design of new and refurbished earthen buildings. Additionally, it is necessary to analyse if in this type of buildings there are parameters that can influence their 


\begin{tabular}{|c|c|}
\hline \multicolumn{2}{|c|}{ Nomenclature } \\
\hline RH & Relative Humidity (\%) \\
\hline$\varnothing$ & Diameter \\
\hline met & Metabolic rate \\
\hline clo & $\begin{array}{l}\text { Thermal insulation provided by garments and } \\
\text { clothing ensembles }\end{array}$ \\
\hline$\Theta_{0}$ & Operative Temperature $\left({ }^{\circ} \mathrm{C}\right)$ \\
\hline$\Theta_{\mathrm{rm}}$ & Outdoor running mean temperature $\left({ }^{\circ} \mathrm{C}\right)$ \\
\hline $\mathrm{CO}_{2}$ & Carbon dioxide (ppm) \\
\hline $\mathrm{hPa}$ & Absolute pressure \\
\hline U-value & Heat transfer coefficient $\left(\mathrm{W} /\left(\mathrm{m}^{2} .{ }^{\circ} \mathrm{C}\right)\right)$ \\
\hline IAQ & Indoor Air Quality \\
\hline nZEB & nearly Zero Energy Building \\
\hline
\end{tabular}

thermal performance in a different way from the one considered in the methodology of the thermal regulation.

Besides the very high thermal inertia of this type of buildings, it is also relevant to analyse the combined effect of other passive strategies usually present in this type of vernacular buildings that might also influence their thermal performance.

\subsection{The importance of vernacular strategies for an environmentally responsive building design}

The interest in studying vernacular architecture within the scope of sustainability is increasing since its features and strategies are the basis for what is now defined as a sustainable building design [6].

The industrialisation of construction (materials, systems, etc.) led to the standardisation of buildings. All over the world, regardless of climatic context, buildings became more similar. As a consequence, they became more dependent on heating, ventilation, and air conditioning (HVAC) systems to satisfy comfort conditions, which led to the routine installation and operation of these mechanical systems, even if not necessary. This situation led to the disregard for the vernacular knowledge, changing not only the way buildings and indoor spaces were designed (commonly arranged by function and thermal needs) but also the occupants' living habits [7]. These issues have been discussed by several authors [7-10], since it is not possible to globally standardise humans and environments, and local-specific factors that influence comfort, such as climate, cultural and social habits, that must also be taken into account.

However, nowadays, climate-indifferent buildings are still largely built. Therefore, the paradigm must move towards climate and environmentally-responsive building designs [11]. On this subject, vernacular architecture is a particularly interesting research topic, since several building techniques and forms have been developed over time to address specific local conditions better $[12,13]$. In recent years, several qualitative and quantitative studies, developed in different regions of the world, have reported similar conclusions, e.g. that is possible to archive acceptable comfort conditions in vernacular buildings during most of the year by passive means alone [6,14-18] and that vernacular strategies are effective and still practicable nowadays. Thus, this empiric knowledge could contribute towards reducing the heating/cooling energy demand of the buildings [10,19-21].

The case of vernacular earthen architecture is a relevant research topic since earth is used as a building material/technique for over 9000 years and a third of world's population is still living in earthen buildings [22]. Earthen techniques are generally connoted with poverty and underdevelopment but, in the last decades, the interest for these techniques has increased due to the raising awareness on environmental issues [23,24]. Some studies have shown that the use of local materials, including earthen ones, can significantly reduce the environmental impacts of buildings $[19,25,26]$. Therefore, environmental issues can be the turning point in favour of earthen materials. Moreover, there are also social and health advantages [1,14,19,22,27], such as the opportunity to preserve a cultural legacy, to educate and train skilled construction workers on vernacular techniques and the fact that these materials have low toxicity and the ability to regulate moisture.

Rammed earth is a traditional monolithic wall construction technique, dating back to 5000 B.C., well-known worldwide [22], where moist earth is poured into a formwork in layers compacted by ramming. This technique seems to have been developed independently in China and around the Mediterranean basin [28]. In the Iberian Peninsula, and particularly in Portugal, this building technique has been used for over two thousand years, as described by Vitruvius and Pliny the Elder, i.e. centuries before the arrival of the Moors to the region [28,29]. Nevertheless, the latter were probably responsible for spreading the technique in the south of Portugal [30].

In the 18th century, the use of rammed earth in Europe had a new impulse by the publications of Goiffon and Cointeraux [28,31]. In the 20th century, rammed earth gained importance as a building solution to the housing shortages following each world war, and from the 1970s forward, different groups around the world began to investigate the properties of rammed earth scientifically [28]. Also in the 20th century, the development of the electric and pneumatic rams allowed to significantly increase productivity and reduce time and labour intensity [22].

In Portugal, the interest on rammed earth is increasing, namely in the southern part of the country, with a small number of builders specialised in building with this material. Some professionals argue that the cost of this type of construction is still not competitive in comparison to conventional solutions, even with the mechanisation of the construction process. However, the growing interest and importance given to sustainability issues can contribute to promoting the use of this technique in new constructions, allowing to reduce its cost.

\subsection{Aim of this research}

In Portugal, the study of the vernacular architecture within the scope of sustainability is still in the first stages. There are only few studies, mainly qualitative, focusing on the passive strategies used and their thermal performance. The few quantitative studies conducted so far [14,15,32-34] focused on quantifying the contribution of the passive strategies used in Portuguese vernacular buildings, but there is still a lack of results from in situ measurements that demonstrate the influence of these strategies on the thermal performance.

Regarding the vernacular architecture of Alentejo, analysing the state-of-art, it is possible to conclude that there are no quantitative studies on the thermal performance of vernacular rammed earth buildings that cover all seasons. Additionally, it is necessary to analyse this type of buildings according to the standards of comfort, and more specifically using the adaptive model of comfort. Only by verifying if vernacular earthen buildings comply with the thermal regulation in force and comfort standards can show, or not, if this type of architecture has a better thermal performance than conventional buildings.

The aim of this work is to contribute to the development of this field of research by analysing the thermal performance of a vernacular earthen building located in the southern part of the 
country, considering the thermal comfort standards, and analysing how the earthen building techniques suit the specific local conditions. To achieve this goal, the indoor thermal performance of a rammed-earth building was assessed, by measuring hygrothermal parameters that characterise the indoor thermal environment and that affect the occupants' thermal comfort.

As an outcome, this research will contribute to a better understanding of the properties of this type of architecture, by assessing the impact of using the studied vernacular design principles and building materials in improving the thermal behaviour of both new and renovated buildings.

\section{Materials and methods}

To achieve the proposed goal, the methodology adopted in this study is guided by a set of appropriate standards and models. The in situ measurements were divided into short and long-term monitoring and were carried between the summer of 2014 and the winter of 2016:

a) Short-term monitoring - it was carried out at least one day per season and consisted of objective measurements and subjective evaluation. The objective measurements had the purpose of quantitatively assess the thermal comfort conditions in a specific room using a thermal microclimate station (model Delta OHM 32.1) that measures air temperature, relative humidity, mean radiant temperature and air velocity (Table 1), in compliance with standards ISO 7726 [35] and ISO 7730 [36]. The placement of the equipment is based on the distribution of the occupants in the rooms. The measurements were performed considering that the occupants were seated, as recommended in ASHRAE Standard 55 [37]. The data recorded in this

Table 1

Characteristics and location of the measurement equipment used.

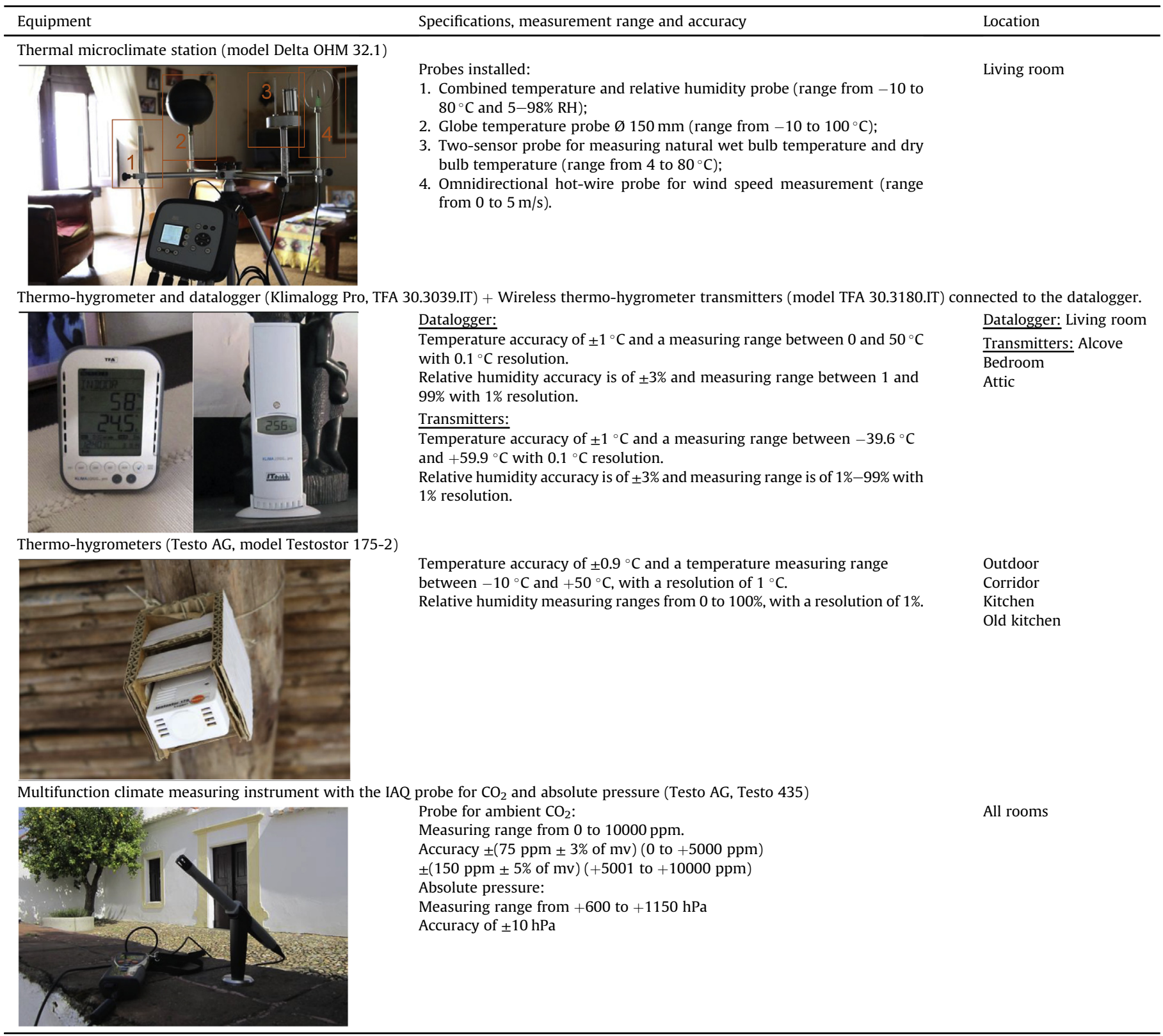


measurement was used to assess the Operative Temperature (the analysis procedure is explained below in this section). Simultaneously, subjective evaluation, based on questionnaires, was carried out to assess the perceived indoor environment quality by the occupants. During the measurements, the case study building was occupied by four occupants, two females (35 and 65 years old) and two males ( 35 and 65 years old). The survey allowed to evaluate the occupants' satisfaction according to the ASHRAE thermal sensation scale and was based on the "Thermal Environment Survey" from ASHRAE standard 55 [37]. The results of these two types of analysis were compared.

b) Long-term monitoring - it was carried out to measure the indoor and outdoor air temperatures and relative humidity throughout the measurement period. For this purpose, thermohygrometer sensors were installed outdoors and indoors, in the most relevant rooms of the case study (Table 1 ). The measurements were carried out in compliance with specified procedures and standards [35-37]. The monitoring campaign was carried out for all seasons of the year, in periods of at least 25 days, recording data at $30 \mathrm{~min}$ intervals. The correlation between indoor and outdoor microclimate parameters was analysed.

Additionally, during the measurements, occupants were asked to fill an occupancy table, where they recorded how they used the building in their daily life, e.g., if they switched on heating or cooling systems, promoted ventilation, used shading systems. These occupancy records were useful to analyse the influence of the occupants' behaviour in the indoor microclimate and to understand unexpected changes in air temperature and relative humidity values. Local weather data was collected from the nearest weather station.

In the analysis of thermal comfort conditions, an adaptive model of thermal comfort was used, since this is the adequate model for naturally conditioned buildings. To be more representative of the Portuguese reality, the chosen model was the Portuguese adaptive model of thermal comfort [38]. This model is an adaptation to the Portuguese context of the models specified in standards ASHRAE 55 [37] and EN 15251 [39]. This model considers the typical Portuguese climate and ways of living and how buildings are conventionally designed and used. According to this model [38]: i) occupants may tolerate broader temperature ranges than those indicated for mechanically heated and/or cooled buildings; ii) the outdoor temperature has a strong influence on occupants' thermal perception/sensation.

In the application of the proposed model, the following conditions were considered: (i) the occupants have sedentary activity levels with metabolic rates (met) ranging from 1.0 to 1.3 met; (ii) the occupants may freely adapt their clothing to the indoor and/or outdoor thermal conditions (clo); (iii) air velocity is below $0.6 \mathrm{~m} / \mathrm{s}$; (iv) indoor operative temperature varies between $10^{\circ} \mathrm{C}$ and $35^{\circ} \mathrm{C}$; (v) outdoor running mean temperature is between $5^{\circ} \mathrm{C}$ and $30^{\circ} \mathrm{C}$.

In the Portuguese adaptive model, two comfort temperatures ranges are defined, one for spaces with active air-conditioning systems and the other for buildings without those systems or with those systems turned off. In this model, the operative temperature $\left(\Theta_{0}\right)$ limits were defined for $90 \%$ of acceptability, based on the outdoor running mean temperature $\left(\Theta_{\mathrm{rm}}\right)$. These limits are up to $3{ }^{\circ} \mathrm{C}$ above or below the estimated comfort temperature, that is defined by Equation (1) for non-air-conditioned spaces and Equation (2) for air-conditioned spaces.

$\Theta_{\mathrm{o}}=0.43 \Theta_{\mathrm{rm}}+15.6$

$\Theta_{\mathrm{o}}=0.30 \Theta_{\mathrm{rm}}+17.9$
The calculation of the point that characterises the thermal environment condition was done according to standard EN15251 [39].

The indoor environment was evaluated and classified based on the methodology of standard EN15251 [39] to allow the comparison between the performance of the case study and other buildings. In this analysis, the classification of the indoor environment was applied individually to representative rooms of the case study for the two most demanding seasons (winter and summer). Since the building has no cooling system and the heating devices are operated sporadically, for simplification, it was considered that the building is occupied during the $24 \mathrm{~h}$.

The air quality was evaluated by measuring the carbon dioxide $\left(\mathrm{CO}_{2}\right)$ concentration in the building when it is fully occupied since occupants were the main source of $\mathrm{CO}_{2}$ emissions [39]. The measurements were carried out for representative rooms and days in all seasons, in compliance with standard EN15251 [39]. The equipment used is a multifunction climate measuring instrument with the IAQ probe for $\mathrm{CO}_{2}$, temperature, humidity and absolute pressure. Table 1 presents the characteristics and location of the used measurement equipment.

\section{Description of the case study}

In inland Southern Portugal, the vernacular architecture developed specific mitigation strategies, that in general are more focused on passive cooling during summer, as mentioned in previous publications [11,14,15]. From these strategies, the heavy earthen walls stand out for keeping indoor temperature and relative humidity stable, as observed in other studies $[14,16,40]$, particularly during summer, and are an element that characterises vernacular architecture from this region $[30,41]$. The use of rammed earth in the region is ancient, and the flat terrain, dry climate and the abundance of clayey material were favourable factors to the use of earthen materials in a large scale [30].

\subsection{Site and climate}

The case study is located in Safara, a small village in the municipality of Moura, district of Beja, inland Southern Portugal (Fig. 1).

It is implanted next to a plain area of fertile soils rich in clay, and to limestone and calcareous formations [42,43], factors that were favourable for using this resources as building materials - the clayey soils for rammed earth, tiles and bricks; and the limestone to produce lime for plasters and whitewash. The urban layout of the village is compact with a mix of narrow and wide streets, composed mostly of single-storey buildings (Fig. 1). This region has a Mediterranean climate, sub-type Csa, with hot and dry summer, being one of the hottest Portuguese regions during summer (Fig. 2a) [44]. The annual average mean temperature is $17.5^{\circ} \mathrm{C}, 12.5^{\circ} \mathrm{C}$ in winter (Fig. 2b), while in summer is between $22.5 / 25.0^{\circ} \mathrm{C}$ (Fig. 2c) [44]. Summer is the most demanding season in this area. The average maximum air temperature in summer varies between 30 and $35^{\circ} \mathrm{C}$ [44], reaching maximum temperatures of $40^{\circ} \mathrm{C}$ or $45^{\circ} \mathrm{C}$ in some days, and the number of days with a maximum temperature above or equal to $25^{\circ} \mathrm{C}$ is around 110 days [44] (Fig. 2d). The annual average rainfall is below $500 \mathrm{~mm}$, and July is the driest month (below $5 \mathrm{~mm}$ ) [44].

\subsection{Building}

The building chosen is representative of inland southern vernacular architecture, presenting a range of strategies to minimise heat gains and to promote passive cooling. All the original 


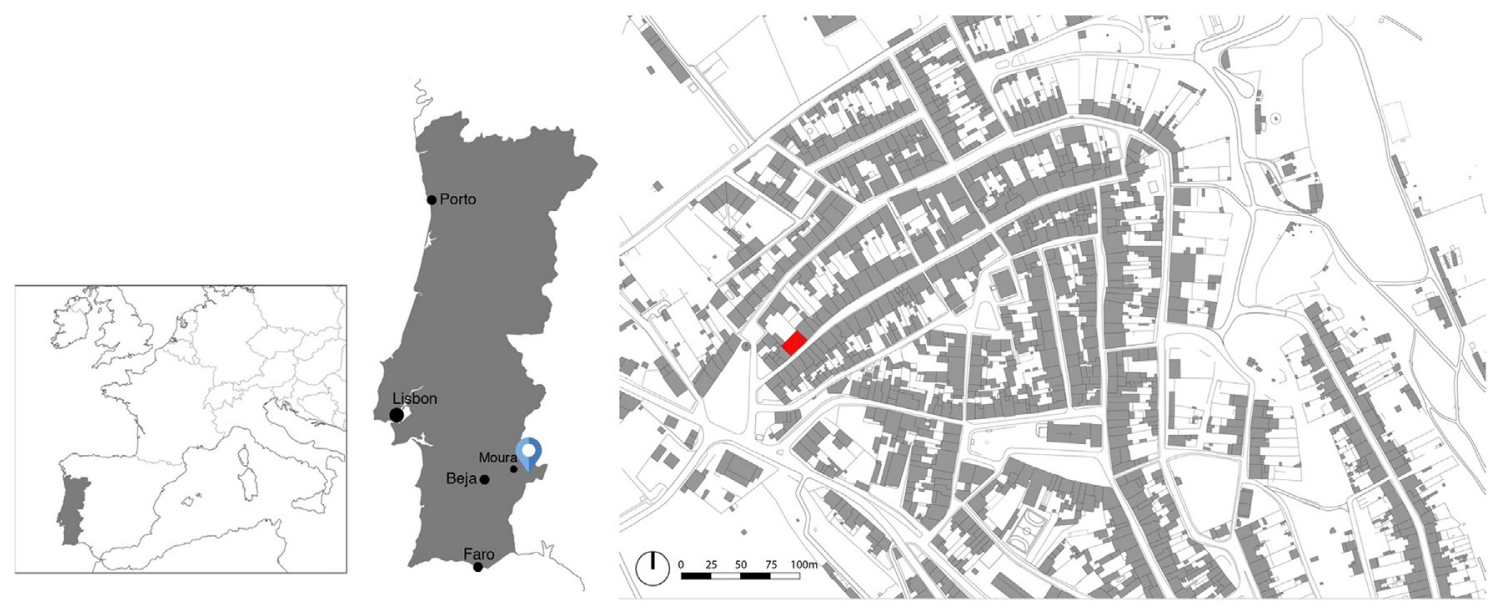

Fig. 1. Case study's location. (left) country context; (right) Safara's urban layout.

building elements and techniques were preserved and maintained. It was not possible to identify the date of construction but, according to the owners, it is probably from the 19th century. This building was renovated in 1983 and this intervention, beyond the maintenance of some building elements, introduced some improvements such as bathroom facilities, insertion of glass in windows (original windows had only wooden shutters), and the function of some rooms was changed as the old kitchen that was transformed into a small living room.

The case-study is integrated into an urban mesh, in a row of buildings forming a street front (Fig. 1). It has main and rear facades facing southeast (street) and northwest (patio), respectively (Fig. 3). The gross floor area is of approximately $200 \mathrm{~m}^{2}$ divided into two storeys.

The upper storey is just a small attic area (originally a granary). On the ground floor, facing southeast, are the living areas and the bedrooms, and in the northern part are the kitchen and the bathroom (Fig. 4). A vaulted corridor connects these two parts, that is also the connection between the street and the courtyard (Fig. 5a). Most of the construction elements used in the building are made of earthen materials. The building envelope consists of whitewashed rammed earth walls (average thickness of $60 \mathrm{~cm}$ ) with a pitched roof, wooden doors and wooden framed single glazed windows (Fig. 5b). Indoors, the partitions walls are in rammed earth, and several of the indoor spaces are vaulted, and the floor is paved with baldosa - a sun-dried clay tile (Fig. 5c-d). It is relevant to highlight the existence of small ventilation shutters above the glazed window to promote controlled natural ventilation, which are particularly useful for night cooling, without compromising the safety of the occupants (Fig. 5e). The building has no air-conditioning system. It has a wood-burning stove (Fig. 5f), and occupants use sporadically electric fan heaters to heat some rooms. Table 2 lists the thermal transmittance coefficient (U-value) of the building envelope.

\subsection{Passive strategies}

To suit the climatic conditions mentioned, specific mitigation strategies were developed, focusing on passive cooling during summer [11,15]. With this purpose, several vernacular architecture techniques were developed, like the ones found in the case study, such as $[11,15,41,47]$ :

a) the size and number of windows and doors facing the outdoor environment are minimised to reduce solar gains. The use of small windows, recessed in the façade, allows the head and side jambs of the window to work as a shading element (Fig. 3);

b) the use of high thermal inertia building elements, namely rammed-earth walls and vaulted ceilings, allows a first dampening of the external thermal wave and keeps the indoor temperature and relative humidity more stable. The vaulted ceilings also allow to increase the height of the indoor spaces and therefore the thermal stratification (Fig. 5c);

c) the use of light colours for the building envelope, mainly whitewashed surfaces, to reflect the incident solar radiation (Fig. 3);

d) ventilation openings that are integrated into windows and doors, to promote air circulation and night cooling to remove diurnal thermal loads. This technique allows ventilation without compromising privacy and security (Fig. 5b, e);

e) the patio (courtyard) allows not only to create a private outdoor space but also to generate a microclimate close to the building. In this case, the patio has trees and several flower beds, useful to shade the ground and the building and also to generate a cooling effect through the evapotranspiration of plants;

f) the urban layout, namely the use of narrow streets, is also a strategy used to reduce heat gains by the building envelope (Fig. 1).

The combination of all these strategies allows achieving indoor thermal comfort conditions during the summer season by passive means alone. This aspect highlights the advantages of a holistic understanding of the available resources.

The long tradition in applying the abovementioned strategies in the region, beyond a cultural influence, is a consequence of their effectiveness in mitigating the effects of the climate, as shown in previous studies $[14,15]$. In this sense, the quantitative study of these passive strategies and their effect on the thermal performance of buildings is useful to the discussion about energy efficiency in buildings, as this is described and discussed in the following sections of this paper.

\subsection{Occupancy profile}

Occupant's daily habits influence the thermal performance of a building, and the occupancy profile is synthesised in Table 3. During the monitoring, the building was kept in a free-running mode most of the time. 

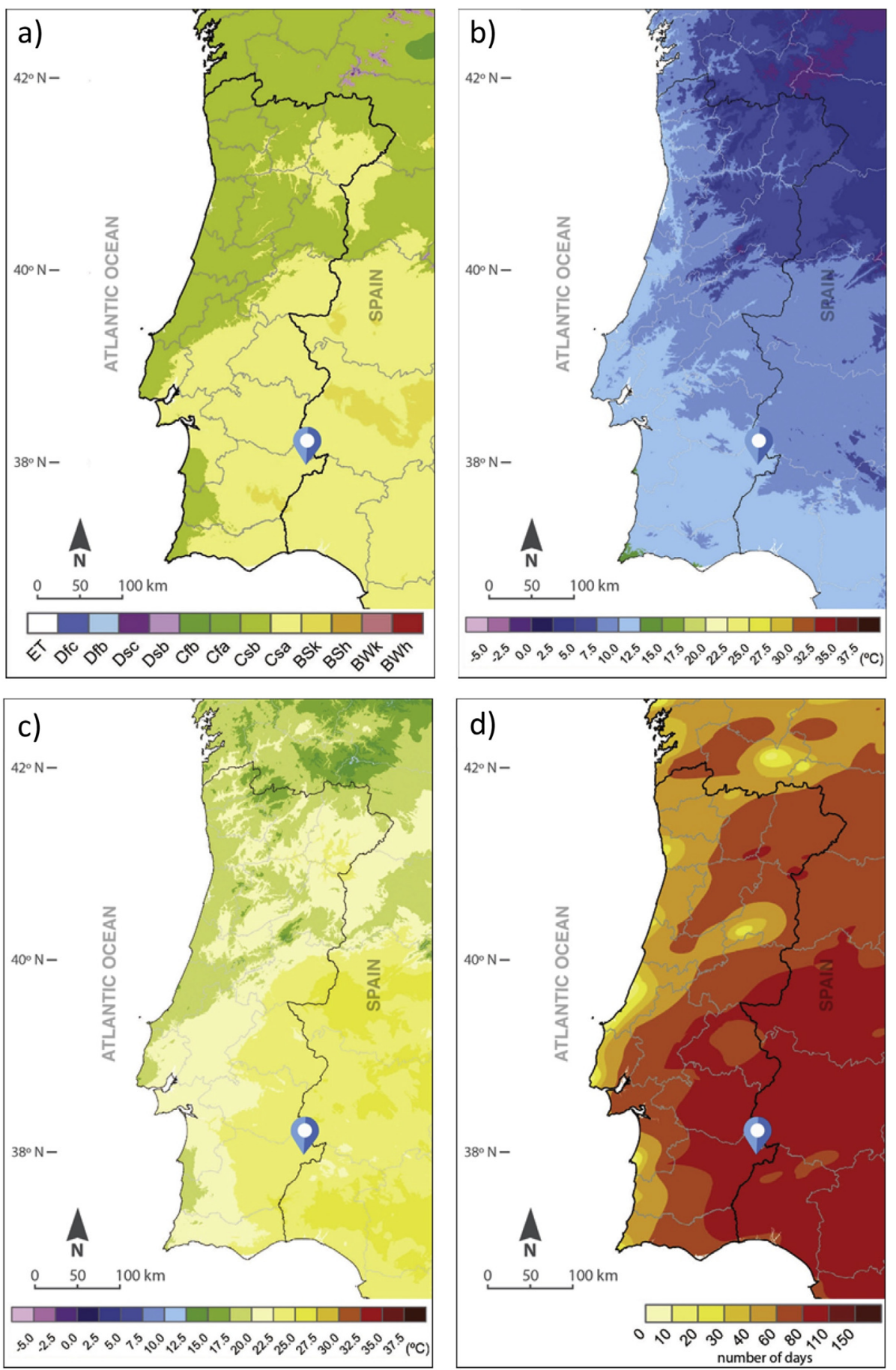

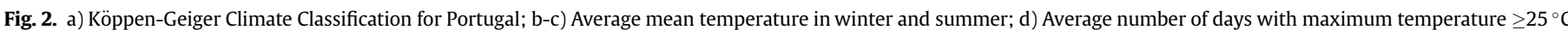
in summer (adapted from Ref. [44]).

\section{Results and discussion}

\subsection{Thermal monitoring and indoor comfort evaluation}

The thermal performance monitoring and indoor comfort evaluation were carried out for all seasons. The data obtained in thermal monitoring is presented for approximately 30 representative days of each season. In this chapter, the results are addressed and discussed.

\subsubsection{Autumn}

During Autumn monitoring (10th November to 19th December 2014), the outdoor mean air temperature was of about $12.5^{\circ} \mathrm{C}$ (Table 4). The daily maximum and minimum air temperatures have significative variations almost during all the monitoring period, with a clear difference between the first and second half of the monitoring period (Fig. 7a). Although the daily outdoor temperature varies between 5 and $10^{\circ} \mathrm{C}$, it is found that indoor temperature remained very stable over the monitoring period with a slight 


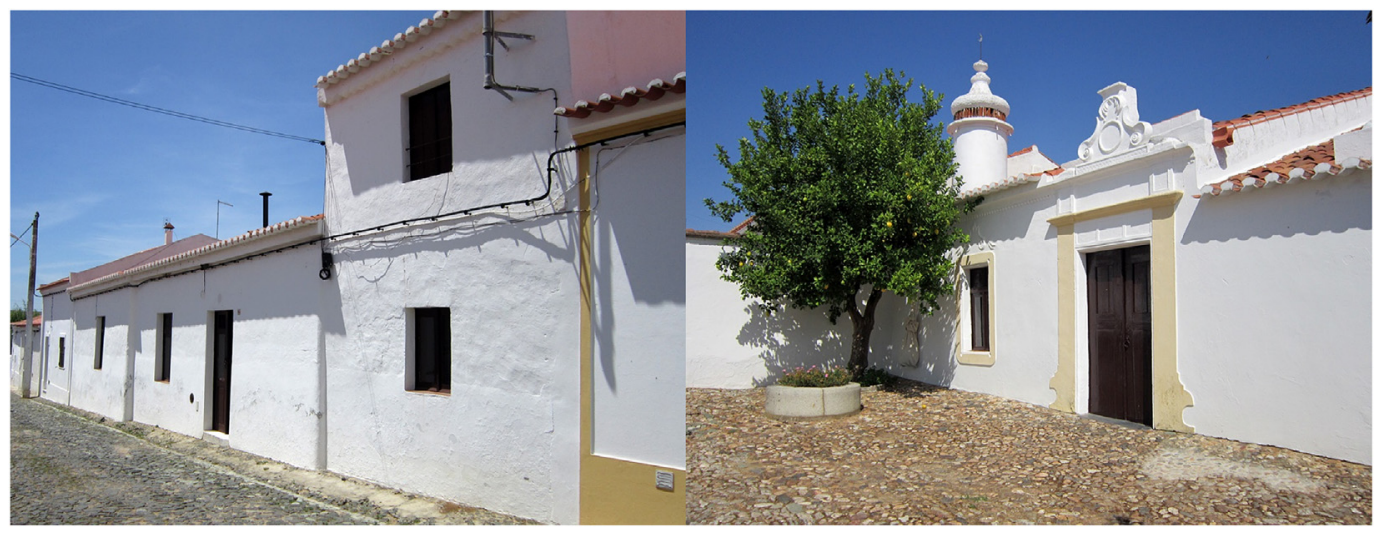

Fig. 3. External views. (left) southeast façade; (right) northwest façade.
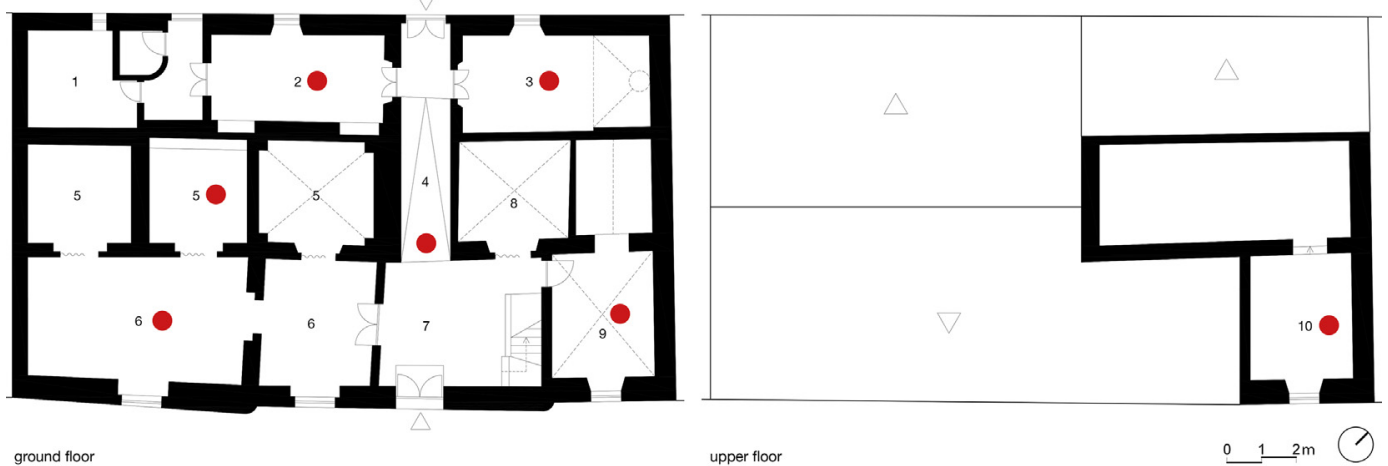

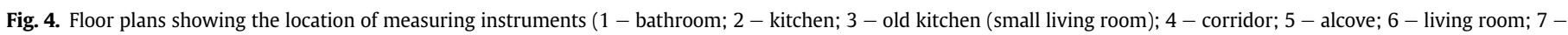
entrance; 8 - library; 9 - bedroom; 10 - attic).

decrease in the second half (around $4^{\circ} \mathrm{C}$ ) (Fig. 6a). The rooms that are occupied during most of the time (living room, alcove, bedroom, and kitchen) have average temperatures between $17.4^{\circ} \mathrm{C}$ and $18.5^{\circ} \mathrm{C}$, as shown in Table 4 . These average values show that rooms are near to the bottom comfort threshold defined by the standards $\left(18^{\circ} \mathrm{C}\right)$. The occupants used heating devices only in the coolest days and during short periods (Table 3 ). The use of these systems is easily visible by the temperature peaks in some hours of the day (Fig. 6a). Therefore, for a free-running building without thermal insulation in the majority of its envelope and without a heating system permanently operating to maintain a constant temperature, the building has an interesting temperature profile for this season, with stable temperatures (even if in some cases below the $18^{\circ} \mathrm{C}$ comfort threshold) and considerably above the ones recorded outdoors. The rooms with sporadic occupation (attic, corridor, and old kitchen), showed similar stable profiles but with values slightly below the ones of the other rooms. This behaviour is due to their position, orientation, and use. The high thermal inertia of the building envelope justifies this behaviour, delaying the effect of outdoor temperature variation and stabilising indoor temperature.

The value of the average outdoor relative humidity was high (84\%). In contrast, indoor spaces have stable relative humidity profiles with small day/night fluctuations and considerably lower average values (Fig. 6b; Table 4). The main rooms have relative humidity values above $60 \%$ most of the time - the maximum recommended for human health and comfort in new buildings $[39,48]$. Nevertheless, the small difference to the recommended humidity range values and the difference between indoor and outdoor values should be highlighted. The hygroscopic inertia and the capacity of rammed earth walls and lime renders to absorb moisture are responsible for this good behaviour.

Regarding the assessment of the thermal comfort (Fig. 7), the measurement of the thermal environment conditions was conducted during a day, with and without the heating system active. During autumn and without the heating system active, the results show that the thermal comfort conditions in the living room (where the occupants remain longer during the day) are slightly higher than the lower comfort limit. With the use of the woodburning stove, it was possible to reach thermal comfort conditions in the living room close to the upper level of the comfort temperature range. From the temperature profile (Fig. 6a), it can be seen that it is possible to reach comfort temperatures with a simple heating system rapidly. Nevertheless, in other rooms, it was verified that the thermal sensation was below the thermal comfort limits and a heating system is necessary to achieve thermal comfort conditions.

In the "thermal environment survey", occupants expressed their thermal sensation in the following way: 1) when the wood-burning stove was "OFF", all occupants answered as being "slightly cool" (1.0 met; $0.88-0.98$ clo); 2 ) when the wood-burning stove was "ON" the occupants answered as being "neutral" (comfortable) (1.0 met; $0.75-1.25$ clo). The differences in clothing insulation are related to the thermal sensation of each occupant that depend on different factors, such as: age, gender, and psychological condition. The results from subjective evaluation validated the objective measurements. 

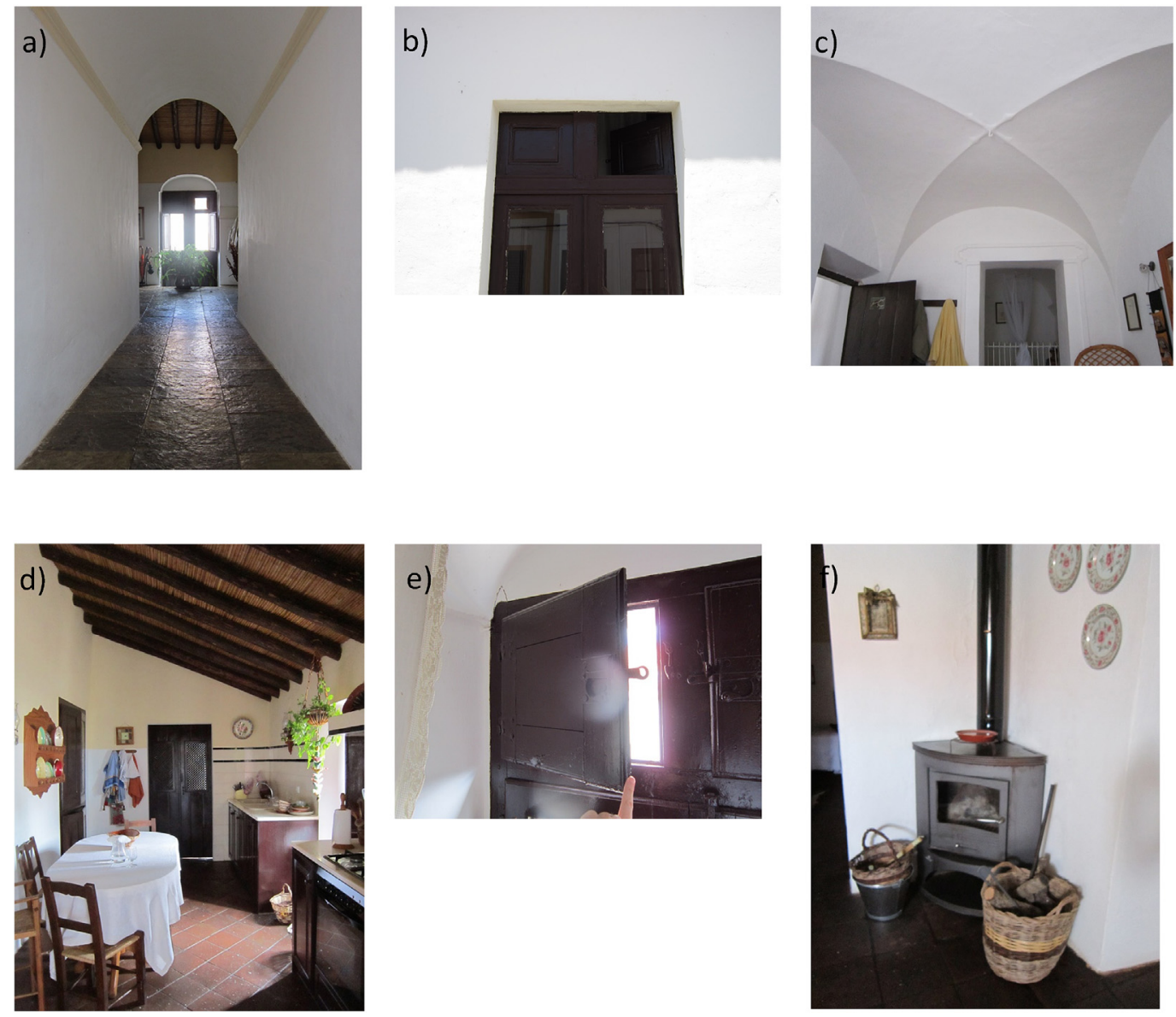

Fig. 5. (a) Indoor corridor; (b) Wooden-window; (c) vaulted room; (d) kitchen view; (e) ventilation shutter; (f) Wood-burning stove.

Table 2

Characteristics of the building envelope.

\begin{tabular}{|c|c|c|}
\hline Envelope element & Materials & U-value $\left(\mathrm{W} /\left(\mathrm{m}^{2} .{ }^{\circ} \mathrm{C}\right)\right)$ \\
\hline External Walls & Rammed earth & $1.30[45]$ \\
\hline Roof & Ceramic tiles, an insulation layer of sprayed polyurethane foam (SPF) and reeds on timber structure & $0.49[46]$ \\
\hline Doors & Wood & $2.15[46]$ \\
\hline Windows & Wooden frame, single glass, indoor wooden shutters & $3.40^{\mathrm{a}}[46]$ \\
\hline
\end{tabular}

${ }^{\text {a }} \mathrm{U}_{\mathrm{wdn}}$ - day-night thermal transmittance coefficient, including the contribution of shading systems.

\subsubsection{Winter}

In the winter monitoring, carried out between 22nd December 2014 and 8th February 2015, the outdoor mean air temperature was of $7.3^{\circ} \mathrm{C}$, with the maximum often above $12^{\circ} \mathrm{C}$ and minimum usually below $5^{\circ} \mathrm{C}$, reaching on some days nearly $0^{\circ} \mathrm{C}$ (Fig. 8a; Table 5). In this season, the graph of indoor temperatures shows several peaks due to the use of heating devices, like the woodburning stove and electric fan heaters, in the living room, and the kitchen and bedroom, respectively (Fig. 8a).

In a period when the occupants were out (between 5 th to 8 th January), it is possible to see the passive behaviour of the building and a gradual stabilisation of the indoor temperatures. In the living room, after the turn-off of the wood-burning stove, temperature values took about $24 \mathrm{~h}$ to decrease from 24 to $18^{\circ} \mathrm{C}$, and more than $50 \mathrm{~h}$ to reach $15^{\circ} \mathrm{C}$. At the same time, the temperature in the alcove next to the living room took more than $80 \mathrm{~h}$ to decrease from 19 to $15^{\circ} \mathrm{C}$. This slow temperature decrease is explained by the thermal inertia and high heat storage capacity of the building elements, particularly the massive external and internal walls. If with short heating periods the temperature decrease is slow, it could be expected that with longer heating periods the temperature stabilisation will reduce the energy use for heating. Further studies are needed to confirm this since long heating periods are not common in Portuguese living habits.

Although the bedroom is a space where higher temperature values are expected, compared with the other occupied spaces it is the one with the lowest temperatures (slightly below $15^{\circ} \mathrm{C}$ ). The occupants heat the room only until they feel comfortable to undress/dress on the morning and at night and this is visible in the temperature peaks of about $18^{\circ} \mathrm{C}$ in those periods of the day (Fig. 8a). The attic and the old kitchen are not heated areas and presented a stable temperature value around $12^{\circ} \mathrm{C}$.

In what relative humidity is concerned, maximum outdoor values were frequently around 90\% (Fig. 9b) and indoor rooms with longer occupation periods had lower daily variations and average values between 50 and 65\% (Table 5). The living room and the 
Table 3

Housing occupancy profile - frequent uses.

\begin{tabular}{|c|c|c|}
\hline Season & & Use and description \\
\hline \multirow[t]{3}{*}{ Spring } & heating/cooling & $\begin{array}{l}\text { Sporadic heating is used in cool days (March and April). The pattern is: wood-burning stove ( } 6 \text { p.m.- } 11: 30 \text { p.m.); fan heater in the } \\
\text { kitchen ( } 1 \mathrm{~h} \text {, three times per day during meals) and in the main bedroom (10 p.m.-10:30 p.m.). }\end{array}$ \\
\hline & ventilation & $\begin{array}{l}\text { Daily opening of the ventilation shutters in the living room and bedroom ( } 9 \text { a.m.-1 pm, until the middle of May; 7:30 a.m.-9:30 } \\
\text { a.m., from the middle of May till June). }\end{array}$ \\
\hline & shading & $\begin{array}{l}\text { From the middle of May, the main façade (SE) windows and shutters are closed until } 2 \text { p.m.; rear façade (NW) windows and } \\
\text { shutters are closed between } 2 \text { p.m. and } 8 \text { pm. }\end{array}$ \\
\hline \multirow[t]{3}{*}{ Summer } & heating/cooling & No cooling or heating systems are used \\
\hline & ventilation & Daily opening of the ventilation shutters all around the house ( 6 a.m.-9 am). \\
\hline & shading & $\begin{array}{l}\text { Main façade (SE) windows and shutters are closed from } 9 \text { a.m. to evening; rear façade (NW) windows and shutters are closed } \\
\text { between } 2 \text { p.m. and } 8 \text { pm. }\end{array}$ \\
\hline \multirow[t]{3}{*}{ Autumn } & heating/cooling & $\begin{array}{l}\text { Heating (from middle November forward). The pattern is: wood-burning stove (working days, between } 6 \text { p.m. and } 11: 30 \text { p.m.; } \\
\text { weekends and holidays, from } 11 \text { a.m. to 11:30 p.m.); Fan heater in the kitchen ( } 1 \text { h, three times per day during meals) and the } \\
\text { main bedroom (between } 10 \text { p.m. and 10:30 p.m.). }\end{array}$ \\
\hline & ventilation & Sporadic opening of the ventilation shutters (between 9 a.m. and 11 a.m.) is used. \\
\hline & shading & No shading is used. \\
\hline \multirow[t]{3}{*}{ Winter } & heating/cooling & $\begin{array}{l}\text { Heating (for all season). The pattern is: wood-burning stove (working days, between } 6 \text { p.m. and } 11 \text { p.m.; weekends and holidays, } \\
\text { between } 11 \text { a.m. and 11:30 p.m.); fan heater in the kitchen ( } 1 \mathrm{~h} \text {, two to three times per day during meals) and in the main } \\
\text { bedroom (between } 10 \text { p.m. and 10:30 p.m.). }\end{array}$ \\
\hline & ventilation & Sporadic opening of the ventilation shutters (between 9 a.m. and 11 a.m.). \\
\hline & shading & No shading is used. \\
\hline
\end{tabular}

Table 4

Comparison between outdoor and indoor air temperatures and relative humidity values during the autumn.

\begin{tabular}{|c|c|c|c|c|c|c|c|c|}
\hline \multicolumn{9}{|l|}{ Autumn } \\
\hline Place/room & Outdoor & Living room & Alcove & Bedroom & Attic & Corridor & Old kitchen & Kitchen \\
\hline \multicolumn{9}{|c|}{ Temperature $\left({ }^{\circ} \mathrm{C}\right)$} \\
\hline Mean & 12.5 & 18.4 & 18.5 & 17.5 & 15.8 & 17.3 & 16.1 & 17.4 \\
\hline Maximum & 21.0 & 25.0 & 20.0 & 19.4 & 20.4 & 19.4 & 18.1 & 21.7 \\
\hline Minimum & 3.0 & 15.4 & 16.5 & 14.8 & 11.5 & 14.4 & 12.6 & 13.8 \\
\hline \multicolumn{9}{|c|}{ Relative Humidity (\%) } \\
\hline Mean & 83.8 & 61.5 & 64.8 & 66.8 & 74.0 & 71.6 & 74.0 & 70.9 \\
\hline Maximum & 96.1 & 71.0 & 73.0 & 74.0 & 80.0 & 83.1 & 80.8 & 88.6 \\
\hline Minimum & 58.2 & 38.0 & 52.0 & 53.0 & 68.0 & 59.5 & 67.5 & 53.6 \\
\hline
\end{tabular}

alcove showed values between 40 and $60 \%$ most of the time and this result is influenced by the stove. The bedroom also had a stable profile but with slightly higher values than previously referred rooms. Although the indoor relative humidity values reached in some rooms values above the one recommended for human health $(\leq 60 \%)$, they were considerably lower than the outdoor values and were within the range of $20-70 \%$ for Category III buildings [39]. The lower values and the stability of the indoor relative humidity profiles are due to the hygroscopic inertia of the building elements, namely rammed earth walls, unfired clay tiles (baldosa), lime plaster, which have the capacity to regulate air humidity [1].

Concerning thermal comfort, in this measurement, the woodburning stove was in operation all the time. The results showed that the living room had good thermal comfort conditions, slightly above the middle of the comfort range (Fig. 9). In the context of a cold week $\left(\Theta_{\mathrm{rm}}\right.$ of $\left.5.9^{\circ} \mathrm{C}\right)$, it was only possible to reach adequate thermal comfort conditions when the wood-burning stove was in operation. From the measurements, it is possible to conclude that the conditions [37-39] that allow the use of the air temperature as a proxy for the operative temperature were satisfied. It was also possible to conclude that the alcove has acceptable comfort conditions and that the other rooms were below the thermal comfort limits.

In the survey, three occupants answered as being "neutral" (comfortable) (1.0 met; $1.08-1.31$ clo) and one as being "slightly cool" (1.0 met; 1.04 clo). Although there was one occupant that was slightly uncomfortable, it is possible to conclude that most occupants feel comfortable with the thermal environment and therefore the results from the subjective evaluation corroborated the objective measurements. Compared to the other occupants, the occupant that felt slightly uncomfortable had lower clothing thermal insulation, and this can be an explanation for the different perceived comfort level.

From the results presented above, it was possible to concluded that a heating system is required to achieve thermal comfort conditions during the winter season. The calorific power of the woodburning stove allowed to rapidly increase air temperature to thermal comfort levels in the living room. Its use in the living room is adequate since it is the bigger room and where occupants stay for longer periods. Since the case study is an old building, without a central heating system, the effect of using the electric fan heaters cannot be neglected, even if for short periods. Though not an energy-efficient equipment, the occupants had to use them to quickly increase temperature by convection in the kitchen and the bedroom and to reduce thermal discomfort sensation during meals and dress/undress periods. The sporadic use of this type of equipment is also in line with Portuguese cultural habits of intermittent heating.

The results are in line with other studies devoted to high thermal inertia buildings $[6,16]$, where stable temperatures in the indoor environment were also observed, and that also highlighted the importance of using heating equipment to reach the comfort thresholds.

\subsubsection{Spring}

During spring monitoring (14th April to 9th May 2015), the outdoor mean air temperature was about $18.2^{\circ} \mathrm{C}$, with maximum values often above $20^{\circ} \mathrm{C}$ and minimum values frequently above 

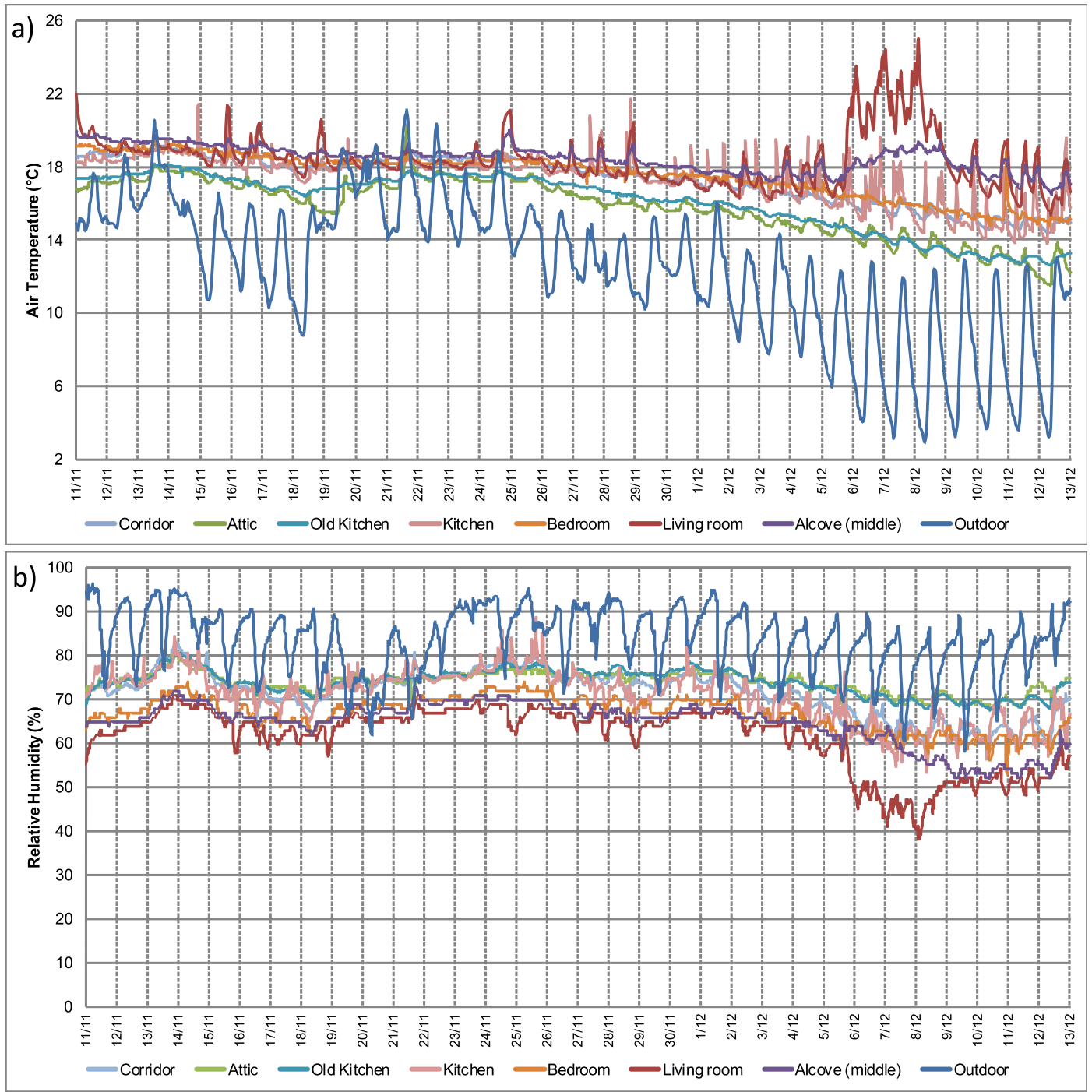

Fig. 6. Autumn: (a) indoor and outdoor air temperature profiles; (b) indoor and outdoor relative humidity profiles.
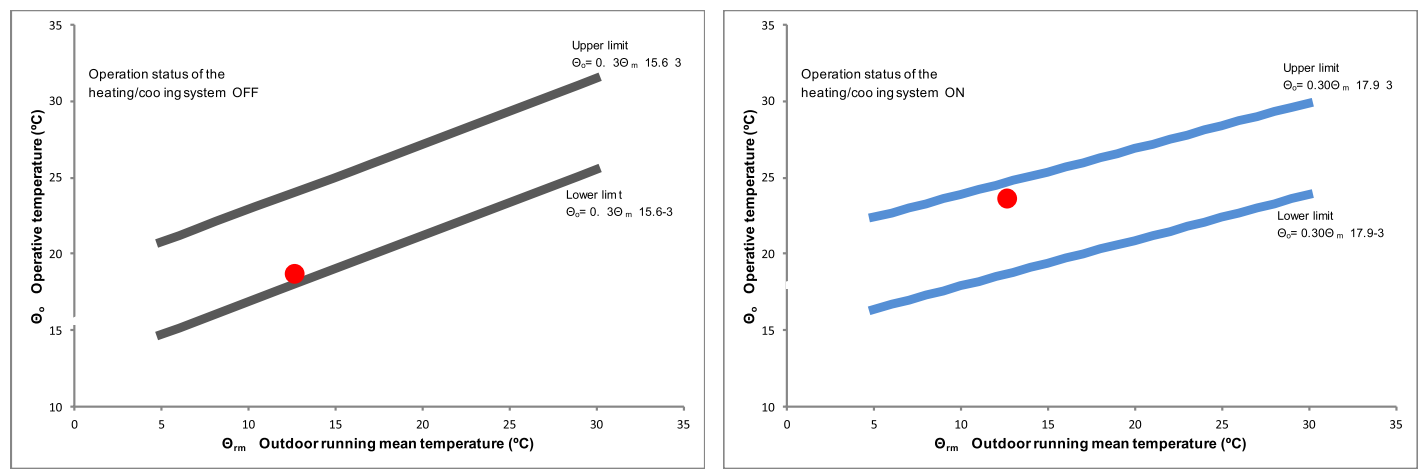

Fig. 7. Adaptive comfort chart. Thermal comfort temperature (operative temperature) in the living room during one representative autumn day.

$10^{\circ} \mathrm{C}$ (Fig. 10a; Table 6). In this monitoring campaign, data for two compartments (corridor and old kitchen) was lost due to equipment errors. Indoor air temperature variations were practically imperceptible, with mean temperature values for the main rooms between 18.3 and $19.1^{\circ} \mathrm{C}$ (Table 6), above the minimum comfort threshold $\left(18^{\circ} \mathrm{C}\right)$ for the heating season.
The variation of the outdoor day/night relative humidity was high, frequently with maximum values around $80 \%$ and minimum between 40 and 50\% (Fig. 10b; Table 6). Indoor mean values were similar (62-69\%) to the outdoor mean value, however, significantly more stable and, in some rooms, with almost no variation. All rooms had relative humidity values above the recommended for 

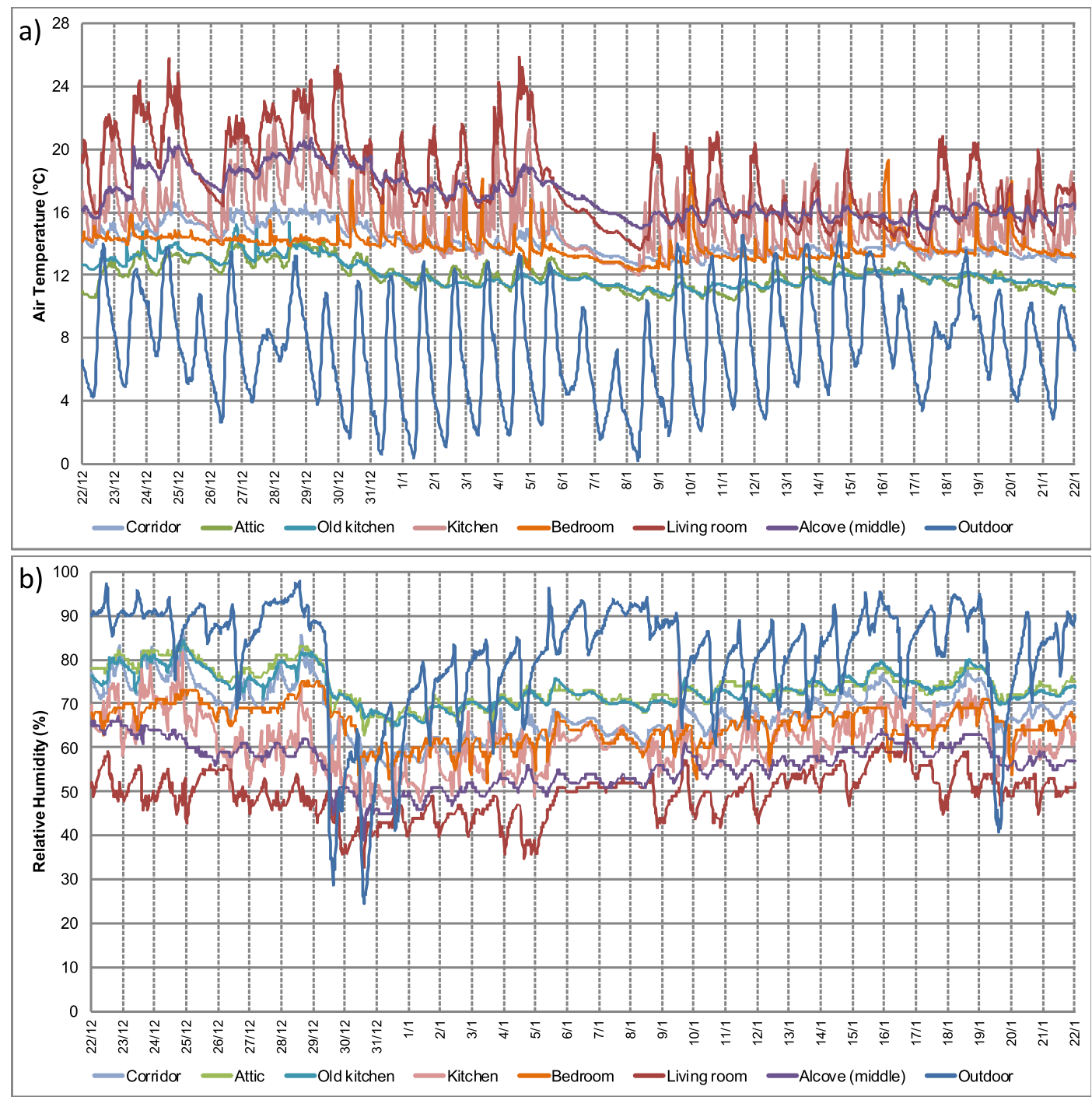

Fig. 8. Winter: (a) indoor and outdoor air temperature profiles; (b) indoor and outdoor relative humidity profiles.

Table 5

Comparison between outdoor and indoor air temperatures and relative humidity values during the winter season.

\begin{tabular}{|c|c|c|c|c|c|c|c|c|}
\hline \multicolumn{9}{|l|}{ Winter } \\
\hline Place/room & Outdoor & Living room & Alcove & Bedroom & Attic & Corridor & Old kitchen & Kitchen \\
\hline \multicolumn{9}{|c|}{ Temperature $\left({ }^{\circ} \mathrm{C}\right)$} \\
\hline Mean & 7.3 & 18.0 & 17.1 & 13.8 & 12.0 & 14.1 & 12.1 & 15.4 \\
\hline Maximum & 14.7 & 25.8 & 20.7 & 19.3 & 14.4 & 16.6 & 15.4 & 22.2 \\
\hline Minimum & 0.2 & 13.6 & 14.9 & 12.3 & 10.4 & 12.6 & 10.7 & 12.2 \\
\hline \multicolumn{9}{|c|}{ Relative Humidity (\%) } \\
\hline Mean & 81.1 & 49.5 & 56.2 & 65.1 & 73.9 & 68.2 & 73.4 & 61.3 \\
\hline Maximum & 97.8 & 63.0 & 67.0 & 75.0 & 84.0 & 86.8 & 84.4 & 81.6 \\
\hline Minimum & 24.7 & 33.0 & 39.0 & 52.0 & 63.0 & 55.2 & 64.9 & 45.8 \\
\hline
\end{tabular}

human health ( $\leq 60 \%)$, but they were very stable, and some were only slightly above this limit.

The thermal comfort assessment was conducted on two different days, one in mid-April and the other in mid-May. The results show that the living room had thermal comfort conditions on the lower limit of the comfort range for both days (Fig. 11).

In the survey carried out in mid-April, the occupants answered as being "neutral" (comfortable) (1.0 met; $0.68-1.25$ clo). In this measurement, one of the occupants had a "clo" value significantly higher (almost the double) than the others. A possible explanation is that there was a physiological factor influencing the perceived thermal comfort of this occupant. In the other survey (mid-May) the occupants answered as being "neutral" (comfortable) (1.0 met; $0.43-0.51$ clo). Although the adaptive comfort graphs (Fig. 11) show a thermal comfort condition in the lower limit, the results from subjective evaluation show occupants' "neutrality", which confirm the results from the objective measurements. In this case, the influence of outdoor conditions in occupants' adaptation is well 


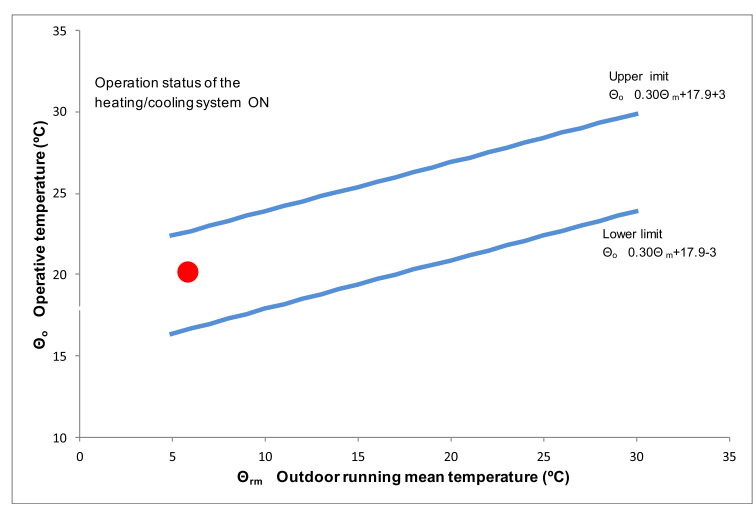

Fig. 9. Adaptive comfort chart. Thermal comfort temperature (operative temperature) in the living room during one representative winter day.

expressed. The charts in Fig. 11 show almost the same thermal sensation for a higher outdoor and indoor temperature, being the clothing thermal insulation considerably different in the two days.

\subsubsection{Summer}

In this monitoring (22nd June to 22nd September 2015), the outdoor mean air temperature was of $28.4^{\circ} \mathrm{C}$, maximum was often above $35^{\circ} \mathrm{C}$, reaching $40^{\circ} \mathrm{C}$ on some days (Table 7; Fig. 12a), and the minimum was usually above $20^{\circ} \mathrm{C}$. In this monitoring period, data was lost for the kitchen due to equipment errors. Although there was a significant daily outdoor temperature variation, with high maximum temperatures, it is verified that indoor temperatures remained very stable over the period, with mean temperature values between 26.7 and $27.1^{\circ} \mathrm{C}$ in the main rooms (Table 7 ; Fig. 12a). The maximum temperature values recorded were slightly higher than the value of the mean temperatures but only express sporadic conditions (less than $2 \mathrm{~h}$ ) (e.g. windows openings, etc.). The attic, due to its location near the roof, had the highest mean air temperature. Nevertheless, it acts as a buffering space, protecting the bedroom below from the outdoor heat.

The indoor temperature profiles showed that the heavy thermal inertia of the building envelope has an important role in delaying the heat transfer process and in stabilising the indoor temperatures. Additionally, the materials/building elements used indoors namely rammed earth partition walls, vaulted ceilings and unfired clay tiles provide additional heat storage capacity, particularly
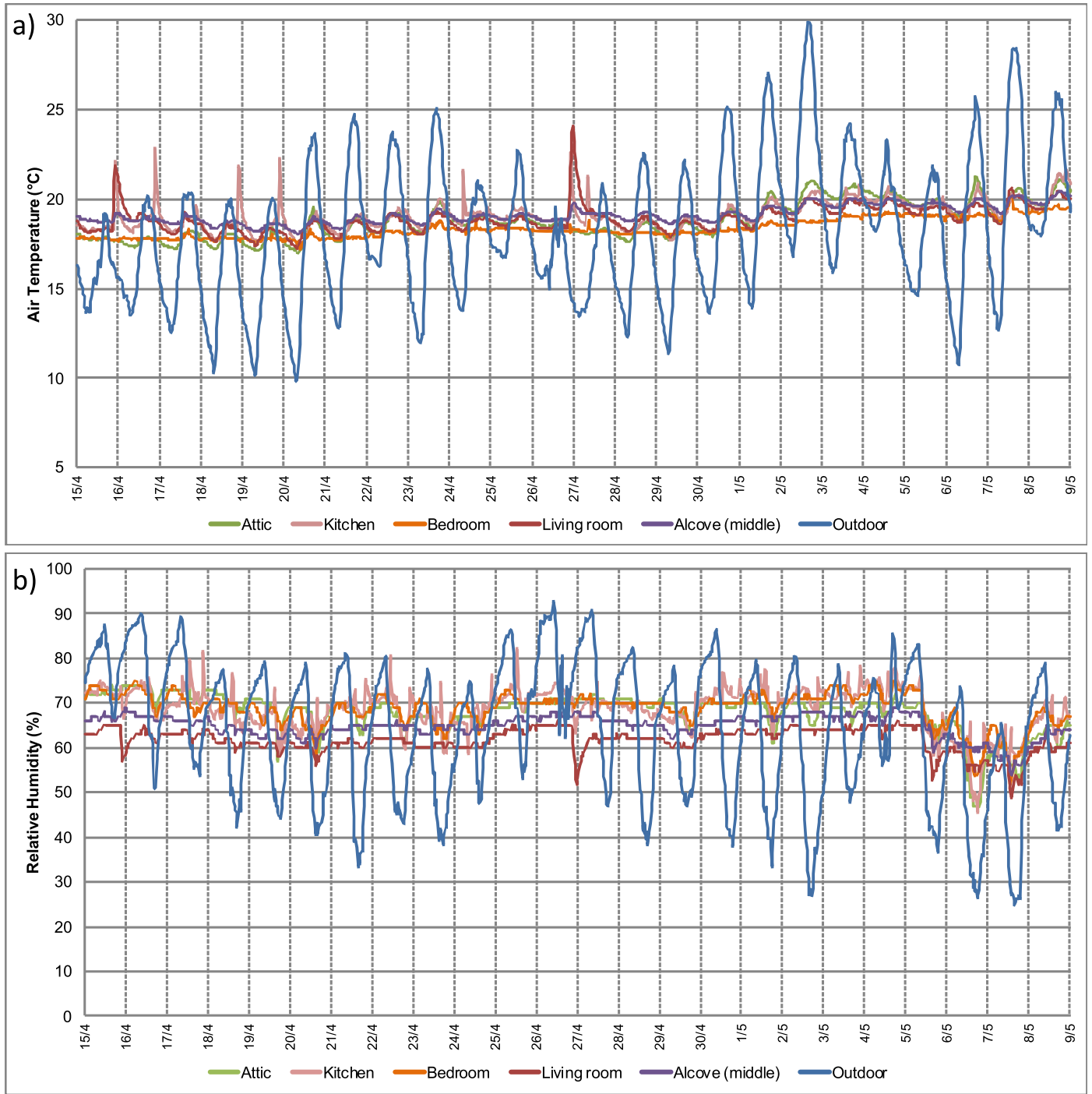

Fig. 10. Spring: (a) Indoor and outdoor air temperature profiles; (b) Indoor and outdoor relative humidity profiles. 
Table 6

Comparison between outdoor and indoor air temperatures and relative humidity values during the spring season.

\begin{tabular}{|c|c|c|c|c|c|c|}
\hline \multicolumn{7}{|l|}{ Spring } \\
\hline Place/room & Outdoor & Living room & Alcove & Bedroom & Attic & Kitchen \\
\hline \multicolumn{7}{|c|}{ Temperature $\left({ }^{\circ} \mathrm{C}\right)$} \\
\hline Mean & 18.2 & 18.9 & 19.1 & 18.3 & 18.8 & 19.1 \\
\hline Maximum & 29.9 & 24.0 & 20.4 & 20.1 & 21.2 & 22.8 \\
\hline Minimum & 9.8 & 17.2 & 18.0 & 17.2 & 17.0 & 17.5 \\
\hline \multicolumn{7}{|c|}{ Relative Humidity (\%) } \\
\hline Mean & 64.2 & 61.6 & 64.9 & 68.8 & 67.9 & 68.7 \\
\hline Maximum & 92.7 & 66.0 & 69.0 & 75.0 & 74.0 & 82.1 \\
\hline Minimum & 25.1 & 49.0 & 54.0 & 52.0 & 46.0 & 45.7 \\
\hline
\end{tabular}
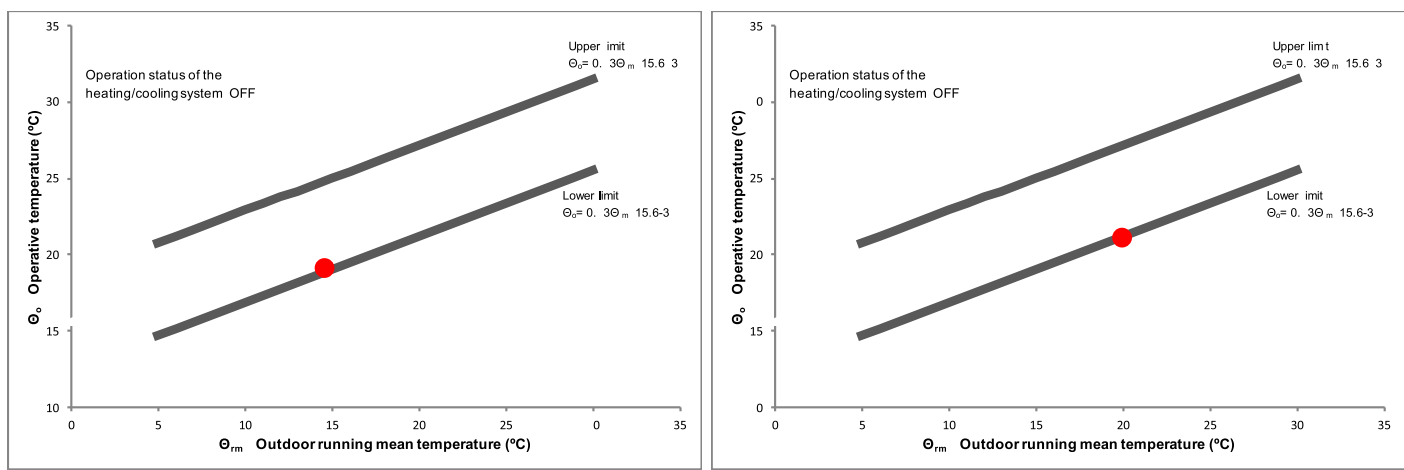

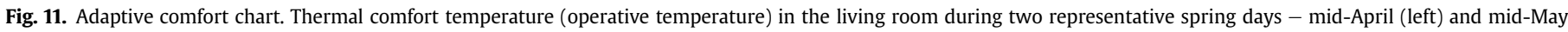
(right).

Table 7

Comparison between outdoor and indoor air temperature and relative humidity values during the summer season.

\begin{tabular}{|c|c|c|c|c|c|c|}
\hline \multicolumn{7}{|l|}{ Summer } \\
\hline Place/room & Outdoor & Living room & Alcove & Bedroom & Attic & Old kitchen \\
\hline \multicolumn{7}{|c|}{ Temperature $\left({ }^{\circ} \mathbf{C}\right)$} \\
\hline Mean & 28.4 & 26.8 & 27.1 & 26.7 & 28.6 & 26.8 \\
\hline Maximum & 40.0 & 28.4 & 28.2 & 27.8 & 30.2 & 30.3 \\
\hline Minimum & 16.9 & 24.2 & 25.1 & 24.9 & 25.2 & 22.2 \\
\hline \multicolumn{7}{|c|}{ Relative Humidity (\%) } \\
\hline Mean & 43.1 & 47.9 & 50.6 & 52.2 & 47.8 & 49.2 \\
\hline Maximum & 78.7 & 58.0 & 60.0 & 61.0 & 55.0 & 64.3 \\
\hline Minimum & 11.9 & 34.0 & 37.0 & 37.0 & 34.0 & 31.5 \\
\hline
\end{tabular}

useful to stabilise indoor temperature during the summer.

For the relative humidity, there was a high outdoor day/night variation (in some cases of about 60\%) (Table 7; Fig. 12b). In contrast, indoor rooms had more stable relative humidity profiles, with fluctuations between $40 \%$ and $60 \%$, within the most appropriate range for human health and comfort [48]. As mentioned before, the differences between indoor and outdoor relative humidity values are justified by the hygroscopic inertia of the building elements.

Regarding the thermal comfort assessment, the results for this season showed that the living room had thermal comfort conditions in the centre of the comfort range (Fig. 13). In the survey, the occupants answered as being "neutral" (comfortable) (1.0 met; 0.35-0.47 clo) and these results confirmed the objective measurements.

To achieve these thermal conditions, the active behaviour of the occupants to improve their comfort conditions should be highlighted. For instance, they promoted passive cooling by natural ventilation during the night and early morning and shutted the doors and windows during the rest of the day, as presented in
Table 3.

From these results, it is possible to conclude that the building has a good thermo-hygrometric performance during the most demanding season of this climate zone, without having mechanical cooling systems, confirming the effectiveness of the used passive cooling strategies. The results of this study are in line with the results and conclusions observed in other studies focusing high thermal inertia buildings in Mediterranean countries [6,16,49], which also highlight, for this type of buildings, the possibility of archiving good comfort conditions during summer by passive means alone.

\subsection{Classification of the indoor environment according to the standard EN15251}

In this section, the indoor environment of the case study is evaluated and classified according to the categories defined by the standard EN15251 [39]. The results are presented as the percentage of time that the selected indoor environment parameters were within the different categories (I, II, III, and IV). The explanation of 

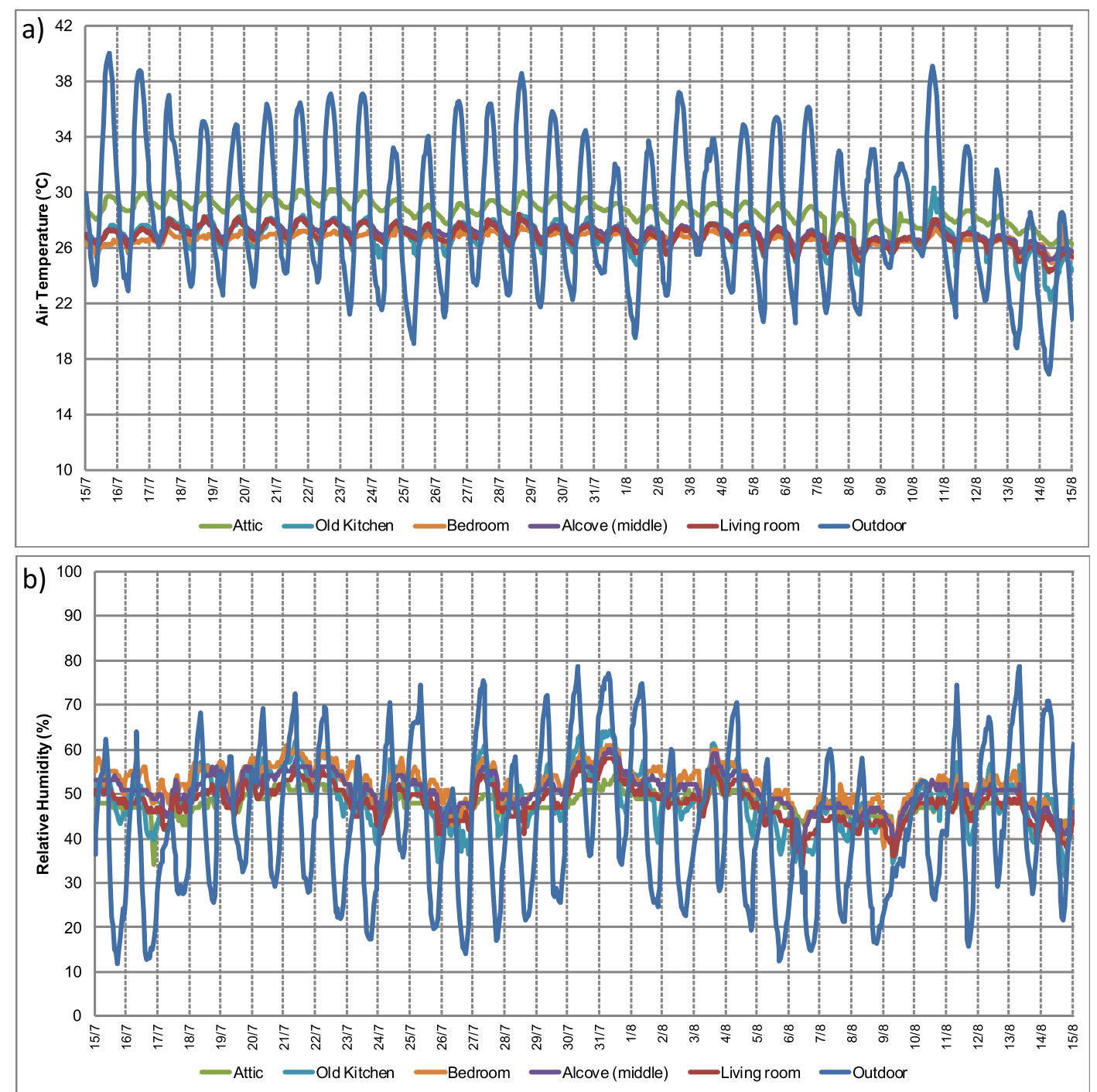

Fig. 12. Summer: (a) indoor and outdoor air temperature profiles; (b) indoor and outdoor relative humidity profiles.

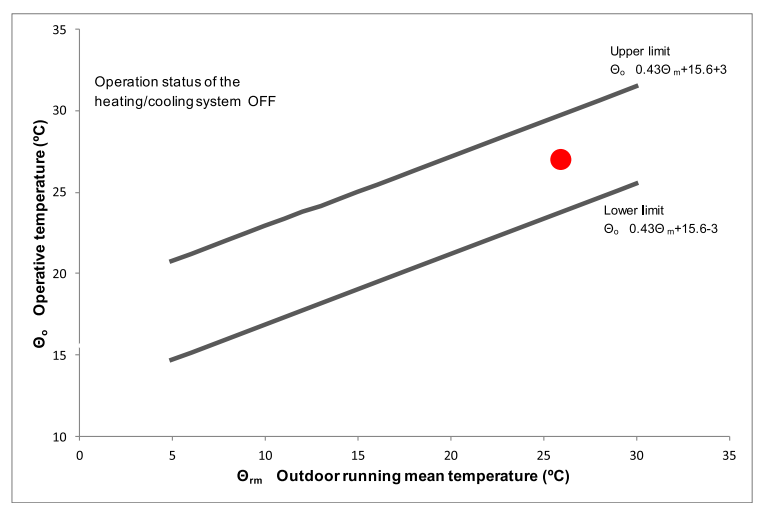

Fig. 13. Adaptive comfort chart. Thermal comfort temperature (operative temperature) in the living room during a representative summer day.

each category is presented in Table 8.

\subsubsection{Thermal criteria for winter and summer}

The range of values used to analyse the two seasons are different, due to the occupancy profile and characteristics of the case study but also to the level of adaptation and expectation of occupants for both seasons. In winter, since active systems are used, the values to design heating systems were considered [39]. During summer, since the building is naturally ventilated and has no mechanical cooling system, the adaptive comfort model was applied. In this case the upper and lower temperature limits for each category are strongly related to the outdoor running mean temperature [39].

During most of the time of the heating season, the thermal conditions in the rooms were out of the limits defined for Category III $\left(18^{\circ} \mathrm{C}\right)$ (Figs. 14-15). In Fig. 14, the points within the range represent heating periods. The living room, as the room with longer occupation periods, had more points within the thermal comfort range than the other rooms due to the use of the wood-burning stove. The bedroom showed the worst performance, but occupants heat it sporadically, only when dressing and undressing their clothes. Regarding the latter, the occupants can accept temperatures below the range mentioned in the standard $\left(18^{\circ} \mathrm{C}\right)$, as it is visible in the ranges of the adaptive model of comfort for Portugal. However, even considering this and that the building is not heated permanently, as it is common in Portugal, the results showed an 
Table 8

Description of the categories to classify the indoor environment according to the standard EN15251 [39].

\begin{tabular}{ll}
\hline Category & Explanation \\
\hline I & $\begin{array}{l}\text { Buildings/spaces for sensitive persons (e.g. for young children and } \\
\text { elderly persons) (high level of expectation) }\end{array}$ \\
II & New buildings and renovations (normal level of expectation) \\
III & Existing buildings (moderate level of expectation) \\
IV & Values outside the criteria for the above categories. This category can \\
& be only accepted for a limited part of the year. \\
\hline
\end{tabular}

inadequate thermal performance during winter. Additionally, if considering the widely stated health problems and mortality rates related to inadequately heated indoor environments $[50,51]$, the minimum indoor temperature of $18{ }^{\circ} \mathrm{C}$, recommended by the standard, must be maintained in indoor living spaces.

Regarding the cooling season, the results confirmed the climateresponsiveness of the building during the most demanding season in this region, since it was most of the time into Category I (the highest level of expectation) (Figs. 15-16). In the remaining time, the building was classified as belonging to Category II. This result shows that this kind of buildings was built to mitigate the intense summer heat, by using only passive cooling strategies to adequately address the thermal comfort of its occupants.

\subsubsection{Humidity criteria}

The standard EN15251 underlines that long term high or low humidity values have an adverse effect by causing microbial growth or irritation of eyes and respiratory tract, respectively. Since earthen materials are considered as having good moisture regulation properties, this analysis is relevant to evaluate the performance of the case study.

As presented in Fig. 17, in winter, the monitored rooms were categorised in a different way. The rooms with the best performance were the living room and the alcove, due to the use of the stove that allowed to reduce the relative humidity. The old kitchen
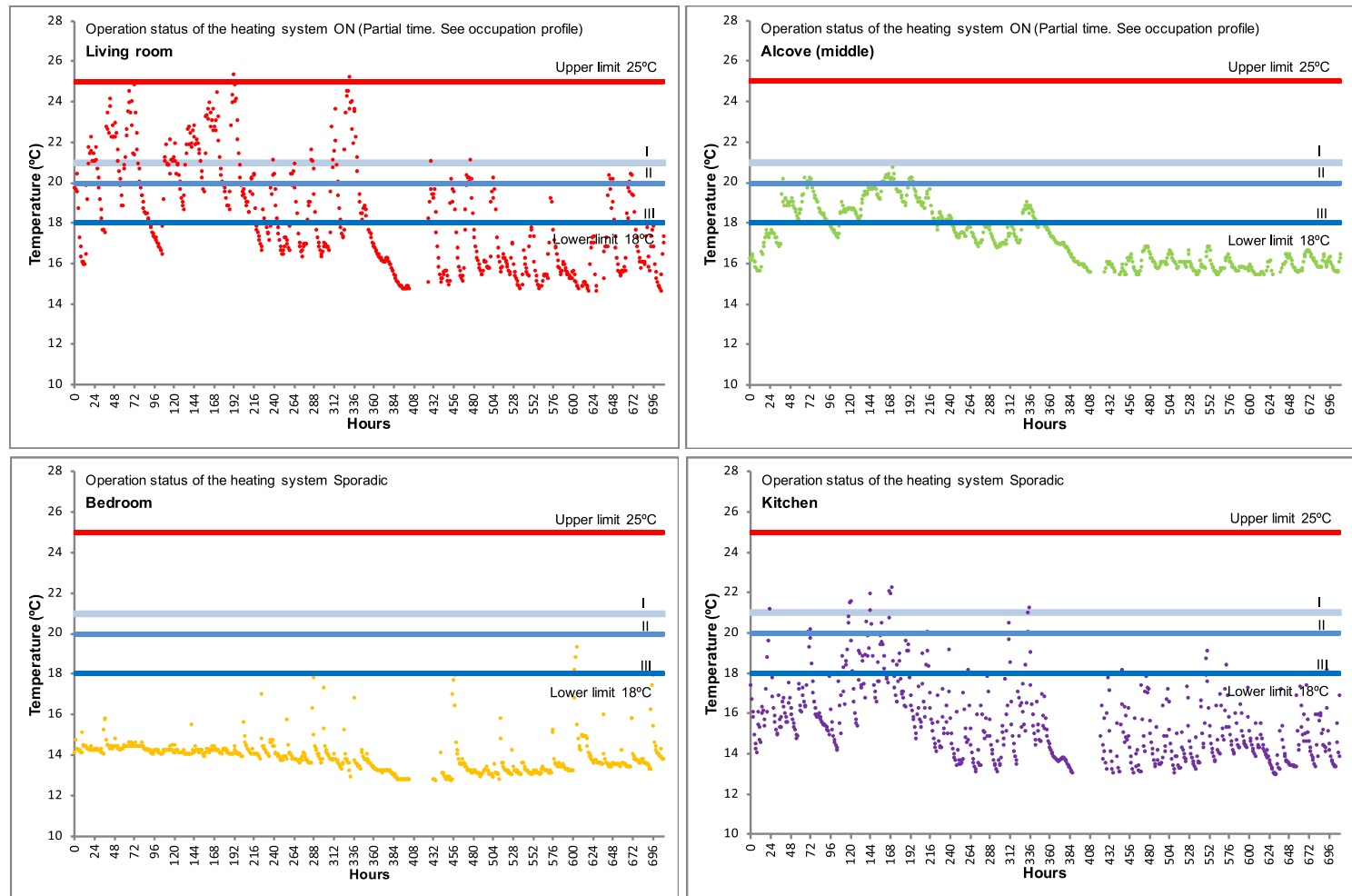

Fig. 14. Thermal conditions in representative indoor rooms during the heating season, according to the limits of each category defined by EN15251.
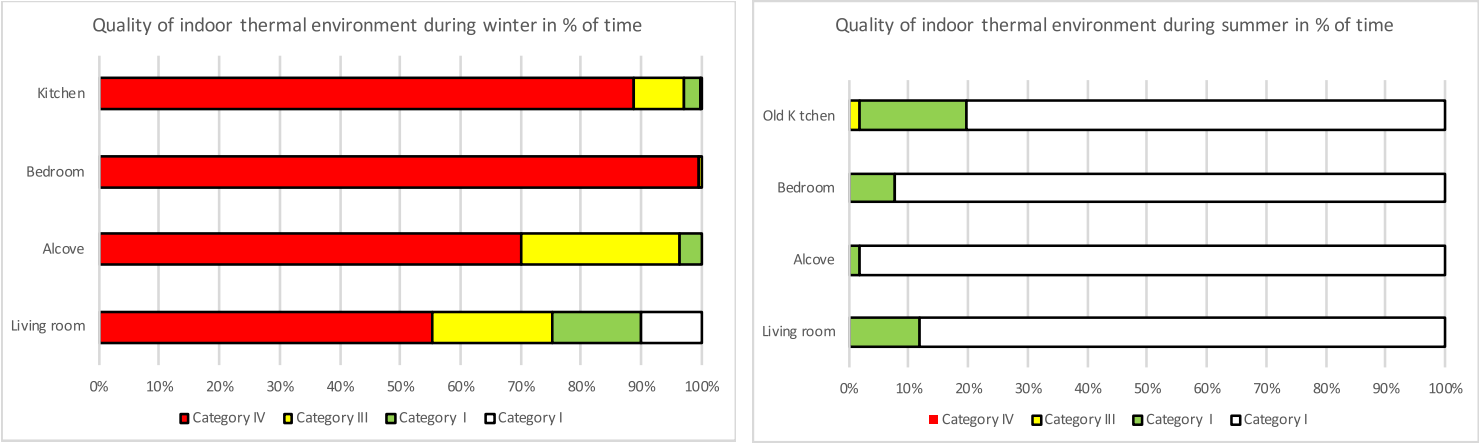

Fig. 15. Classification of indoor thermal environment for representative rooms of the building. (left) Winter; (right) Summer. 

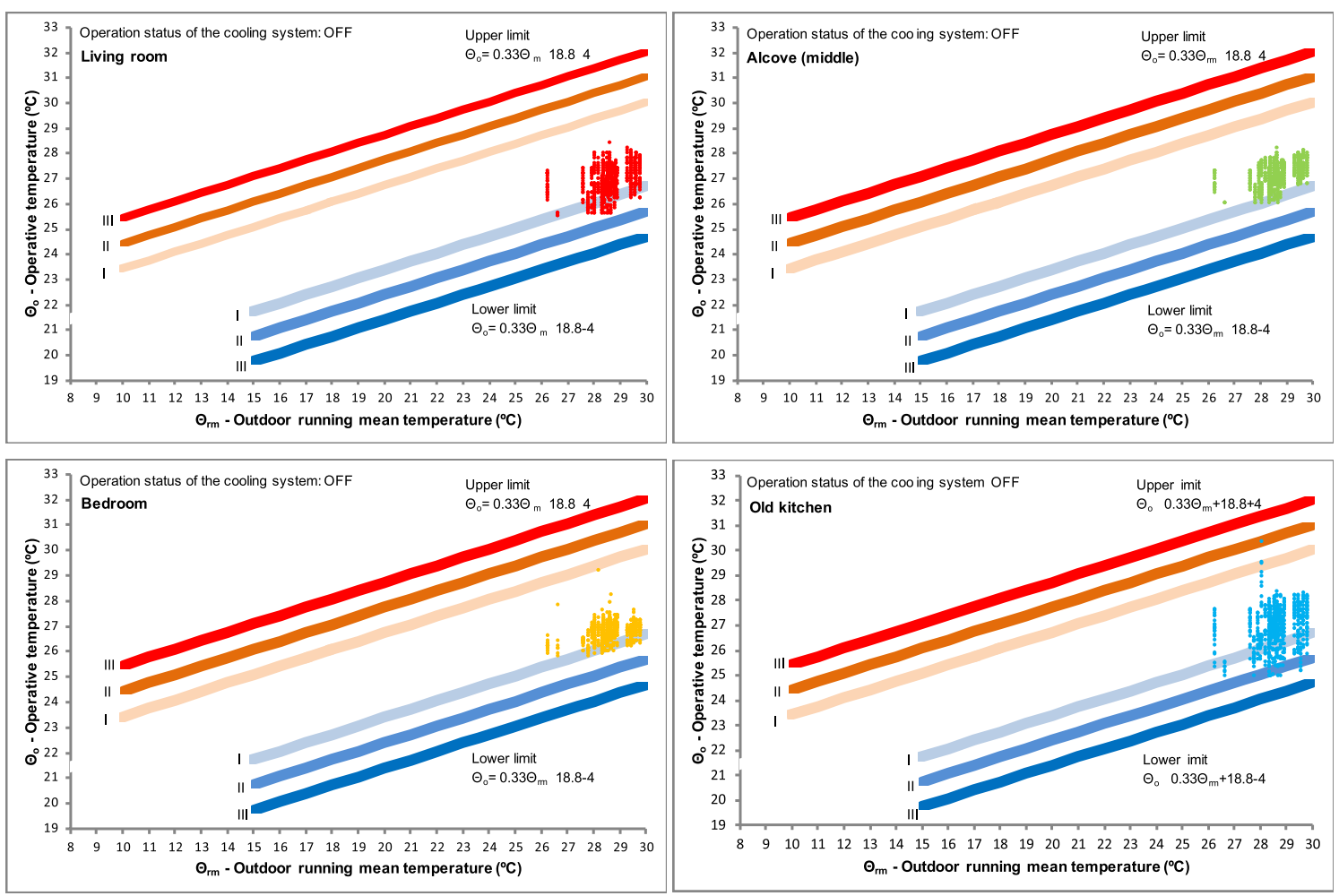

Fig. 16. Thermal conditions in representative indoor rooms during the cooling season, according to the limits of each category defined by EN15251.
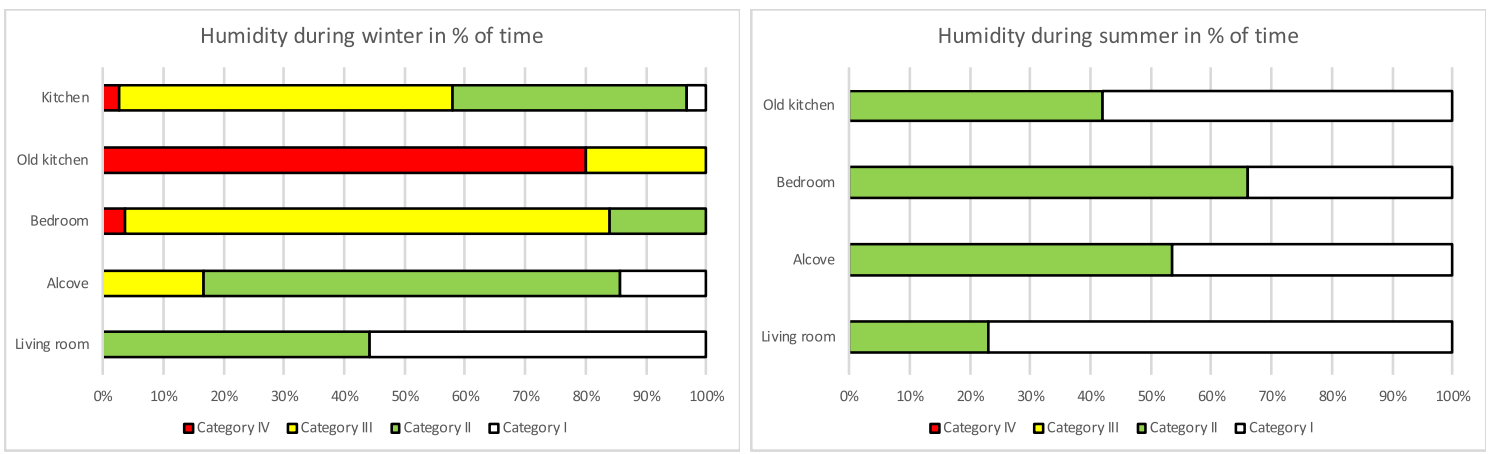

Fig. 17. Classification of indoor humidity for representative rooms of the building: (left) Winter; (right) Summer.

had the worst performance, and this might be caused by the infiltration of the exterior air (with high relative humidity) through the open chimney.

During the summer, all rooms showed a high-performance level (Categories I and II). Although outdoor relative humidity was frequently low in summer, indoor values were stable and at comfort levels.

\subsubsection{Indoor air quality criteria}

In buildings where occupants are the main source of pollution; air quality can be analysed by measuring the carbon dioxide concentration. The carbon dioxide concentrations were measured in different occupied rooms during a representative day of each season. During the winter season, the measurement was carried out in a day with the wood-burning stove in operation (marked with an asterisk in Table 9) to verify the influence of the stove in the $\mathrm{CO}_{2}$ levels.

From the measurements, it was verified that the use of the wood-burning stove does not increase the $\mathrm{CO}_{2}$ concentrations when compared with the summer season (Table 9). The small differences between outdoor and indoor carbon dioxide concentrations can be due to the low occupation density of the building, to the natural ventilation and infiltration rate, to the effectiveness of the wooden-stove exhaust system and the earthen materials pollutants-absorbing properties [22]. Results show that although this is an ancient building, the $\mathrm{CO}_{2}$ concentration levels are within the requisites of the most demanding category.

\subsection{Challenges in the context of the energy performance legislation}

As seen in previous sections, the case study had a high thermal performance during the summer by passive means alone, and stable air temperature and relative humidity profiles during the other seasons. Although this building had adequate thermal performance during most of the year, its building elements do not comply with the minimum requirements for the U-value defined by 
Table 9

Classification of the indoor air quality in representative rooms for all seasons (Asterisk mark $\left(^{*}\right)=$ wood-burning stove ON).

\begin{tabular}{|c|c|c|c|c|c|}
\hline \multicolumn{6}{|c|}{ Carbon Dioxide $\left(\mathrm{CO}_{2}\right)$ concentration } \\
\hline Season & Place/room & Concentration (ppm) & Difference above outdoor & Category & Pressure $(\mathrm{hPa})$ \\
\hline \multirow[t]{7}{*}{ Autumn } & Outdoor & 430 & & & 995 \\
\hline & Living room & 515 & 85 & I & \\
\hline & Alcove & 515 & 85 & I & \\
\hline & Bedroom & 493 & 63 & I & \\
\hline & Kitchen & 545 & 115 & I & \\
\hline & Old kitchen & 515 & 85 & I & \\
\hline & Corridor & 495 & 65 & I & \\
\hline \multirow[t]{7}{*}{ Winter } & Outdoor & 472 & & & 999 \\
\hline & Living room & $620^{*}$ & 148 & I & \\
\hline & Alcove & 600 & 128 & I & \\
\hline & Bedroom & 602 & 130 & I & \\
\hline & Kitchen & 552 & 80 & I & \\
\hline & Old kitchen & 557 & 85 & I & \\
\hline & Corridor & 549 & 77 & I & \\
\hline \multirow[t]{7}{*}{ Spring } & Outdoor & 394 & & & 996 \\
\hline & Living room & 458 & 64 & I & \\
\hline & Alcove & 458 & 64 & I & \\
\hline & Bedroom & 480 & 86 & I & \\
\hline & Kitchen & 471 & 77 & I & \\
\hline & Old kitchen & 494 & 100 & I & \\
\hline & Corridor & 494 & 63 & I & \\
\hline \multirow[t]{7}{*}{ Summer } & Outdoor & 323 & & & 998 \\
\hline & Living room & 465 & 142 & I & \\
\hline & Alcove & 495 & 172 & I & \\
\hline & Bedroom & 462 & 139 & I & \\
\hline & Kitchen & 354 & 31 & I & \\
\hline & Old kitchen & 362 & 39 & I & \\
\hline & Corridor & 408 & 85 & I & \\
\hline
\end{tabular}

the national regulation on the Energy Performance of Buildings [5].

As an example, the $U$-value of a $40 \mathrm{~cm}$ and a $60 \mathrm{~cm}$ thickness rammed earth wall is 1.60 and $1.30 \mathrm{~W} /\left(\mathrm{m}^{2} .{ }^{\circ} \mathrm{C}\right)$, respectively [45]. According to the legal requirements for external opaque vertical elements, the U-values must be lower than 0.35 or $0.50 \mathrm{~W} /\left(\mathrm{m}^{2} .{ }^{\circ} \mathrm{C}\right)$, depending on the climatic zone [5] and therefore it is difficult for earthen building materials alone to satisfy this requirement. Thus, without thermal insulation, it is not possible to meet the minimum thermal insulation level defined by law. The problem seems easy to solve, but the aesthetic aspects, the physical properties of these earthen materials, like the need to "breathe", are incompatible with most used insulation materials and solutions (e.g. External Thermal Insulation Composite Systems - ETICS).

Even with this limitation in what the U-value is concerned, and during winter (the season with lower thermal performance), it was found that it is possible to reach adequate comfort conditions when the building is heated with a simple wood-burning stove. Additionally, when the stove is turned off, the air temperature in the room took several hours, days on some occasions, to decrease, therefore maintaining the comfort conditions for long periods.

The main goal of the regulation on defining low U-values is to reduce the energy demand, while increasing thermal comfort conditions and preventing the occurrence of condensations, to achieve the medium-term nZEB targets. Although during the cooling season the low U-value envelopes also contribute to reducing the heat gains, it has the drawback of increasing the difficulty to dissipate internal heat and to cool the indoor environment. This issue is particularly relevant in the specific climate of Southern Portugal and other Mediterranean areas. Additionally, due to climate changes and the related increase in average annual temperatures, it is expected that in these areas, the impact of the cooling season in the annual energy consumption of buildings will rise considerably. It is predicted that the global energy demand for cooling will triple by 2050 [52]. Although the building does not comply with the minimum thermal insulation requirements, it presents adequate thermal comfort conditions. As shown by Verbeke \& Audernaert [53], a high thermal mass has a relevant contribute for improving thermal comfort and reducing the energy demand. In this type of buildings, the very high thermal inertia has a positive contribution in maintaining the indoor environment within the comfort zone, and this feature is not fully conveyed in the Portuguese regulation on the Energy Performance of Buildings [5].

\section{Conclusions}

The results presented in this study show that there is a strong relation of cause and consequence between local conditions and vernacular architecture in inland southern Portugal.

The results of the thermal environment monitoring show that the case-study building presented good or satisfactory indoor thermal comfort conditions during almost all year. As expected, the worst performance was during the winter season, when an active heating system was necessary to overcome the periods of thermal discomfort. However, taking as an example the living room, using simple heating systems, such as a wood-burning stove, it was possible to reach thermal comfort conditions rapidly. The other rooms had temperature profiles out of the comfort zone because occupants heat them sporadically or do not heat it at all. Since there is no central heating system, the occupants used the portable electric fan heaters to heat these rooms, even for short periods. Though not an energy-efficient equipment, using fan heaters is a simple and practical way to increase air temperature by convection and assure a thermal comfort sensation when needed. It should be highlighted that these good results were achieved in a building that is in a free-running mode for most of the time in most of the rooms. For a vernacular building, with single glazed windows and original wooden frames (i.e. with poor air-tightness) and without thermal insulation (except in the roof), it has stable temperature profiles. With more efficient heating systems, and improving the thermal 
insulation of some building elements (e.g. the windows), it would be possible to assure thermal comfort conditions in all rooms during longer periods. However, this topic needs more in-depth research to verify its effectiveness.

The results on the subjective assessment of the occupants' thermal comfort, using a Thermal Environment Survey, validated the objective assessments. These results show that the adaptive model of comfort adjusted to the Portuguese context is adequate to analyse the thermal comfort conditions in Portuguese vernacular buildings.

Regarding relative humidity, the building also had a good performance with values within the comfort range during almost all the year, except for the winter, when the values were slightly higher than the ones of the other seasons. As in the case of the thermal performance, the relative humidity performance had its best results during the summer season. The high thermal and hygroscopic inertia of the envelope, partition walls, ceilings, and floors, were responsible for the stabilisation and regulation of these two parameters. These good results were also confirmed by the use of the EN1525 methodology to categorise the quality of the indoor environment.

Therefore, it is possible to conclude that vernacular architecture from southern Portugal is a climate-responsive architecture, or in a holistic point of view, an environmentally-responsive architecture that is focused on providing an adequate level of thermal comfort during the intense summer heat. As seen in the case study, the passive cooling strategies provided good thermal comfort conditions without the use of any mechanical cooling system. The contribution of these strategies to stabilise indoor temperature and reduce solar gains show that these buildings were conceived to better perform during summer. Nevertheless, these features do not guarantee an adequate thermal comfort environment during the winter, being necessary, among others, to reduce heat losses by the envelope and ventilation. From these strategies, rammed earth walls have to be highlighted, being correct to state that the use of this technique for centuries demonstrates its suitability and close relationship with the geological and climatic conditions of the region. Thus, the preservation of such strategies in existing buildings of this region (or regions with similar conditions) and their implementation in new ones, can contribute to reduce energy demand for cooling and therefore to reduce the life cycle energy consumption of the buildings and related potential environmental impacts. However, despite the presented advantages, these building elements do not comply with the national regulation on the Energy Performance of Buildings, particularly in what the U-value is concerned. This means that the Portuguese thermal regulation is not considering adequately the passive principles used in this type of buildings that allow maintaining high indoor comfort levels for most of the year as, for instance, the very high thermal inertia. It is possible to implement some solutions to overcome the weak performance during the winter, but they will be different whether it is an existing building or a new one. In existing buildings, the optimisation of the windows and the building airtightness, and the insulation of the roof are feasible and will increase buildings performance without renovating the walls. In new buildings, beyond the solutions mentioned before, it will be easier to implement other solutions as the insulation of the envelope and implementation of passive systems to reduce heat losses and increase gains (e.g. Trombe wall).

Rammed earth is being used for centuries in the southern part of Portugal, is one of the most widely vernacular techniques still used today, and therefore it is important to analyse, through quantitative studies as the one presented in this research, the real benefits of using this technique nowadays.

\section{Declarations of interest}

None.

\section{Acknowledgments}

The authors would like to acknowledge the support granted by the FEDER funds through the Competitively and Internationalization Operational Programme (POCI) and by national funds through FCT-Foundation for Science and Technology within the scope of the project with the reference POCI-01-0145-FEDER-029328, and of the Ph.D. grant with the reference PD/BD/113641/2015, that were fundamental for the development of this study. The authors also wish to thank Mr João Cordovil, Mrs Isabel Gaivão and Moura's Municipality for helping this research work.

\section{References}

[1] B. Berge, The Ecology of Building Materials, second ed., Elsevier, Oxford, 2009 https://doi.org/10.1016/B978-1-85617-537-1.00014-7.

[2] D. Ürge-Vorsatz, L.F. Cabeza, S. Serrano, C. Barreneche, K. Petrichenko, Heating and cooling energy trends and drivers in buildings, Renew. Sustain. Energy Rev. 41 (2015) 85-98, https://doi.org/10.1016/J.RSER.2014.08.039.

[3] H. Yoshino, T. Hong, N. Nord, IEA EBC annex 53: total energy use in buildings-analysis and evaluation methods, Energy Build. 152 (2017) 124-136, https://doi.org/10.1016/J.ENBUILD.2017.07.038.

[4] European Parliament and the Council of the European Union, Directive (EU) 2018/844 of the European Parliament and of the Council of 30 May 2018 Amending Directive 2010/31/EU on the Energy Performance of Buildings and Directive 2012/27/EU on Energy Efficiency, 2018. European Parliament and the Council of the European Union, Brussels, https://eur-lex.europa.eu/legalcontent/EN/TXT/?toc=0J\%3AL\%3A2018\%3A156\%3ATOC\&uri=uriserv\%3AOJ.L_. 2018.156.01.0075.01.ENG. (Accessed 4 July 2018).

[5] DL118/2013, Decreto-Lei 118/2013: Sistema de Certificação Energética dos Edifícios, o Regulamento de Desempenho Energético dos Edifícios de Habitacão (REH) e o Regulamento de Desempenho Energético dos Edifícios de Comércio e Servicos (RECS), 2013. Portugal, http://dre.pt/pdf1s/2013/08/ 15900/0498805005.pdf.

[6] N. Cardinale, G. Rospi, P. Stefanizzi, Energy and microclimatic performance of Mediterranean vernacular buildings: the Sassi district of Matera and the Trulli district of Alberobello, Build. Environ. 59 (2013) 590-598, https://doi.org/ 10.1016/j.buildenv.2012.10.006.

[7] S. Healy, Air-conditioning and the 'homogenization' of people and built environments, Build. Res. Inf. 36 (2008) 312-322, https://doi.org/10.1080/ 09613210802076351.

[8] R. de Dear, G. Schiller Brager, The adaptive model of thermal comfort and energy conservation in the built environment, Int. J. Biometeorol. 45 (2001) 100-108, https://doi.org/10.1007/s004840100093.

[9] G.S. Brager, R.J. de Dear, Thermal adaptation in the built environment: a literature review, Energy Build. 27 (1998) 83-96, https://doi.org/10.1016/ S0378-7788(97)00053-4.

[10] S. Saljoughinejad, S. Rashidi Sharifabad, Classification of climatic strategies, used in Iranian vernacular residences based on spatial constituent elements, Build. Environ. 92 (2015) 475-493, https://doi.org/10.1016/ j.buildenv.2015.05.005.

[11] J. Fernandes, R. Mateus, H. Gervásio, S.M. Silva, L. Bragança, The importance of vernacular strategies for a climate responsive building design, in: C.E. de Alvarez, E.A. Nico-Rodrigues, L. Bragança, R. Mateus (Eds.), SBE16 Brazil Port. Sustain. Urban Communities Towar. a Nearly Zero Impact Built Environ, Federal University of Espírito Santo \& University of Minho, Vitória, Brazil, 2016, pp. 429-438. http://hdl.handle.net/1822/43169.

[12] M.K. Singh, S. Mahapatra, S.K. Atreya, Bioclimatism and vernacular architecture of north-east India, Build. Environ. Times 44 (2009) 878-888, https:/ doi.org/10.1016/j.buildenv.2008.06.008.

[13] M. Philokyprou, A. Michael, E. Malaktou, A. Savvides, Environmentally responsive design in Eastern Mediterranean. The case of vernacular architecture in the coastal, lowland and mountainous regions of cyprus, Build. Environ. 111 (2017) 91-109, https://doi.org/10.1016/j.buildenv.2016.10.010.

[14] J. Fernandes, C. Pimenta, R. Mateus, S.M. Silva, L. Bragança, Contribution of Portuguese vernacular building strategies to indoor thermal comfort and occupants' perception, Buildings 5 (2015) 1242-1264, https://doi.org/ 10.3390/buildings5041242.

[15] J. Fernandes, R. Mateus, L. Bragança, J.J. Correia da Silva, Portuguese vernacular architecture: the contribution of vernacular materials and design approaches for sustainable construction, Architect. Sci. Rev. 58 (2015) 324-336, https:// doi.org/10.1080/00038628.2014.974019.

[16] S. Martín, F.R. Mazarrón, I. Cañas, Study of thermal environment inside rural houses of Navapalos (Spain): the advantages of reuse buildings of high thermal inertia, Constr. Build. Mater. 24 (2010) 666-676, https://doi.org/ 
10.1016/j.conbuildmat.2009.11.002.

[17] R. Shanthi Priya, M.C. Sundarraja, S. Radhakrishnan, L. Vijayalakshmi, Solar passive techniques in the vernacular buildings of coastal regions in Nagapattinam, TamilNadu-India - a qualitative and quantitative analysis, Energy Build. 49 (2012) 50-61, https://doi.org/10.1016/j.enbuild.2011.09.033.

[18] M.K. Singh, S. Mahapatra, S.K. Atreya, Thermal performance study and evaluation of comfort temperatures in vernacular buildings of North-East India Build. Environ. Times 45 (2010) 320-329, https://doi.org/10.1016/ j.buildenv.2009.06.009.

[19] J. Fernandes, R. Mateus, L. Bragança, The potential of vernacular materials to the sustainable building design, in: M. Correia, G. Carlos, S. Rocha (Eds.) Vernac. Herit. Earthen Archit. Contrib. Sustain. Dev, CRC Press, Vila Nova da Cerveira, Portugal, 2013, pp. 623-629, https://doi.org/10.1201/b15685.

[20] M.K. Singh, S. Mahapatra, S.K. Atreya, Solar passive features in vernacular architecture of North-East India, Sol. Energy 85 (2011) 2011-2022, https:// doi.org/10.1016/j.solener.2011.05.009.

[21] A. Foruzanmehr, M. Vellinga, Vernacular architecture: questions of comfort and practicability, Build. Res. Inf. 39 (2011) 274-285, https://doi.org/10.1080/ 09613218.2011.562368.

[22] G. Minke, Building with Earth: Design and Technology of a Sustainable Architecture, Birkhäuser, Basel, 2006.

[23] D. Leitão, J. Barbosa, E. Soares, T. Miranda, N. Cristelo, A. Briga-Sá, Thermal performance assessment of masonry made of ICEB's stabilised with alkaliactivated fly ash, Energy Build. 139 (2017) 44-52, https://doi.org/10.1016/ J.ENBUILD.2016.12.068.

[24] M. Dabaieh, More than Vernacular: Vernacular Architecture between Past Tradition and Future Vision, Lund University (Media-Tryck), Lund, 2015.

[25] J. Morel, A. Mesbah, M. Oggero, P. Walker, Building houses with local materials: means to drastically reduce the environmental impact of construction, Build. Environ. 36 (2001) 1119-1126, https://doi.org/10.1016/S03601323(00)00054-8.

[26] B. Venkatarama Reddy, K. Jagadish, Embodied energy of common and alternative building materials and technologies, Energy Build. 35 (2003) 129-137, https://doi.org/10.1016/S0378-7788(01)00141-4.

[27] S.S. Chandel, V. Sharma, B.M. Marwah, Review of energy efficient features in vernacular architecture for improving indoor thermal comfort conditions, Renew. Sustain. Energy Rev. 65 (2016) 459-477, https://doi.org/10.1016/ j.rser.2016.07.038.

[28] P.A. Jaquin, C.E. Augarde, C.M. Gerrard, Chronological description of the spatial development of rammed earth techniques, Int. J. Archit. Herit. 2 (2008) 377-400, https://doi.org/10.1080/15583050801958826.

[29] F. Pinto, Origens da arquitectura de terra em Portugal = Origins of earthen architecture in Portugal, GECoRPA, Pedra e Cal, Rev. Da Conserv. Do Património Arquit. e Da Reabil. Do Edif 6 (2004) 10-11.

[30] O. Ribeiro, Geografia e Civilização - Temas Portugueses, fourth ed., Livraria Letra Livre, Lisboa, 2013.

[31] P. Doat, A. Hays, H. Houben, S. Matuk, F. Vitoux, Construire en terre, CRATerre \& Editions Alternatives, Paris, 1979. https://craterre.hypotheses.org/319.

[32] I. Costa Carrapiço, J. Neila-González, Study for the rehabilitation of vernacular architecture with sustainable criteria, in: M. Correia, G. Carlos, S. Rocha (Eds.), Vernac. Herit. Earthen Archit, Contrib. Sustain. Dev, CRC Press/Balkema, Vila Nova da Cerveira, Portugal, 2013, pp. 581-586.

[33] J. Gonçalves, R. Mateus, T. Ferreira, Continuing tradition: farms in the northeast region of Portugal, in: C. Mileto, F. Vegas, L. Garcia Soriano, V. Cristin (Eds.), Vernac. Archit. Towar. a Sustain. Futur. - Proc. Int. Conf. Vernac. Heritage, Sustain. Earthen Archit., Taylor and Francis - Balkema, Valencia, 2015, pp. 343-348.

[34] J. Fernandes, R. Mateus, L. Bragança, J. Correia da Silva, An analysis of the potentialities of Portuguese vernacular architecture to improve energy efficiency, in: R. Rawal, S. Manu, N. Khadpekar (Eds.), PLEA 2014 - 30th Int. PLEA Conf. Sustain. Habitat Dev. Soc. Choos. W. Forward. Proc, vol. 3, CEPT UNIVERSITY PRESS, Ahmedabad, 2014, pp. 69-76. http://hdl.handle.net/1822/
33222

[35] ISO7726, Ergonomics of the thermal environment e instruments for measuring physical quantities, 2002.

[36] ISO7730, Ergonomics of the Thermal Environment: Analytical Determination and Interpretation of Thermal Comfort Using Calculation of the PMV and PPD Indices and Local Thermal Comfort Criteria, 2005.

[37] ASHRAE, ANSI/ASHRAE Standard 55 - Thermal Environmental Conditions for Human Occupancy, 2004. Atlanta.

[38] L. Matias, TPI65 - Desenvolvimento de um modelo adaptativo para definicão das condicôes de conforto térmico em Portugal, Laboratório Nacional de Engenharia Civil/National Laboratory of Civil Engineering, Lisboa, 2010.

[39] EN15251, Indoor Environmental Input Parameters for Design and Assessment of Energy Performance of Buildings- Addressing Indoor Air Quality, Thermal Environment, lighting and acoustics, 2007.

[40] G. Desogus, L.G. Felice Cannas, A. Sanna, Bioclimatic lessons from Mediterranean vernacular architecture: the Sardinian case study, Energy Build. 129 (2016) 574-588, https://doi.org/10.1016/j.enbuild.2016.07.051.

[41] E.V. Oliveira, F. Galhano, Arquitectura Tradicional Portuguesa, Publicações Dom Quixote, Lisboa, 1992.

[42] SNIAmb, Soil Map of Portugal - Environment Atlas - SNIAmb - Agência Portuguesa Do Ambiente (n.d.), https://sniamb.apambiente.pt/content/geovisualizador?language $=$ pt-pt. (Accessed 14 June 2018).

[43] LNEG, Geological Map of Portugal at 1:1000 000 - Geoportal do Laboratório Nacional de Energia e Geologia (n.d.), http://geoportal.lneg.pt/geoportal/ mapas/index.html. (Accessed 14 June 2018).

[44] AEMET, IM, Atlas Climático Ibérico: Temperatura do Ar e Precipitação (19712000)/Iberian Climate Atlas: Air Temperature and Precipitation (1971/2000, 2011. http://www.ipma.pt/resources.www/docs/publicacoes.site/atlas_clima_ iberico.pdf.

[45] C.A. Pina dos Santos, R. Rodrigues, ITE54 - Coeficientes de Transmissão Térmica de Elementos Opacos da Envolvente dos Edificios, Laboratório Nacional de Engenharia Civil/National Laboratory of Civil Engineering, Lisboa, 2009.

[46] C.A. Pina dos Santos, L. Matias, ITE50 - Coeficientes de Transmissão Térmica de Elementos da Envolvente dos Edificios, Laboratório Nacional de Engenharia Civil/National Laboratory of Civil Engineering, Lisboa, 2006.

[47] J. Fernandes, M. Dabaieh, R. Mateus, L. Bragança, The influence of the Mediterranean climate on vernacular architecture: a comparative analysis between the vernacular responsive architecture of southern Portugal and north of Egypt, in: World SB14 - Sustain. Build. RESULTS, GBCe - Green Building Council España, Barcelona, 2014, pp. 1-7. http://hdl.handle.net/1822/31403.

[48] T. Morton, Earth Masonry - Design and Construction Guidelines, HIS BRE Press, Berkshire, 2008.

[49] G. Desogus, S. Di Benedetto, R. Ricciu, The use of adaptive thermal comfort models to evaluate the summer performance of a Mediterranean earth building, Energy Build. 104 (2015) 350-359, https://doi.org/10.1016/ j.enbuild.2015.07.020.

[50] C.N.B. Grey, T. Schmieder-Gaite, S. Jiang, C. Nascimento, W. Poortinga, Cold homes, fuel poverty and energy efficiency improvements: a longitudinal focus group approach, Indoor Built Environ. 26 (2017) 902-913, https://doi.org/ $10.1177 / 1420326$ X17703450.

[51] B. Atanasiu, E. Kontonasiou, F. Mariottini, Alleviating Fuel Poverty in the EU: Investing in Home Renovation, A Sustainable and Inclusive Solution, 2014. Brussels, http://bpie.eu/wp-content/uploads/2015/10/Alleviating-fuelpoverty.pdf. (Accessed 4 December 2018).

[52] OECD/IEA, The Future of Cooling: Opportunities for Energy-Efficient Air Conditioning, 2018. http://www.iea.org/publications/freepublications/ publication/The Future of Cooling.pdf.

[53] S. Verbeke, A. Audenaert, Thermal inertia in buildings: a review of impacts across climate and building use, Renew. Sustain. Energy Rev. 82 (2018) 2300-2318, https://doi.org/10.1016/J.RSER.2017.08.083. 